\title{
Reading Suetonius in the Seventeenth Century: The First Political Commentaries
}

This is a post-peer-review, pre-copyedit version of an article published in International Journal of the Classical Tradition. The final authenticated version is available online at: http://dx.doi.org/10.1007/s12138-017-0455-5.

\begin{abstract}
[Abstract] In nineteenth-century variorum editions of Suetonius's Lives of the Twelve Caesars, the period 15951671 is traditionally labelled the 'aetas Casauboniana'. Not without reason, it appears, for in those years many scholars continued the tradition of philological and historical-antiquarian commentaries on Suetonius begun by Angelo Poliziano towards the end of the fifteenth century and culminating in the editions by Isaac Casaubon some hundred years later. It must not be forgotten, however, that the early seventeenth century also saw the first printed commentaries promising moral and political observations. The present contribution offers case studies of four such works, which are so far little known and studied: Simon Goulart's notae morales ac politicae (1592), Matthias Bernegger's political disputations (1624, 1654), Jacobus Zevecotius's observationes politicae (1630, 1637) and Johannes Boeclerus's political dissertations (1647). Through close reading and discourse analysis of these varied works, I will explore the authors' motives and methods, asking why and how they sought to make Suetonius's imperial biographies relevant to their own time.
\end{abstract}

\section{Introduction}

In his 1980 article on the reception of Suetonius's Lives of the Twelve Caesars (De vita Caesarum) in the eighteenth century, Glen Bowersock stated that 'after the pioneering work on the text of Suetonius by Isaac Casaubon toward the end of the sixteenth century, little was done with this author until he was taken up in the final third of the next century by the Dutch scholar Graevius at Utrecht." ${ }^{\text {O }}$ One has only to glance at the major bibliographical works, however, to realize that Suetonius's collection of imperial biographies from Caesar to Domitian was far from neglected between the first appearance of Casaubon's commentary edition in 1595 and the editio princeps of Graevius's variorum edition in 1672. In fact, this period witnessed the production of some seventy-five editions, many of them presenting a newly edited text, as well as new commentaries and translations. While scholars such as Fulvio Orsini (1595), Petrus Scriverius (1596), Théodore Marcile (1603), Marcello Donati (1604), Justus Lipsius (1610), Janus Gruterus (1611), Marcus Boxhorn-Zuerius (1632) and Johannes Schildius (1647) continued the tradition of philological and historical-antiquarian commentaries on Suetonius begun by Angelo Poliziano towards the

\footnotetext{
${ }^{1}$ G. W. Bowersock, 'Suetonius in the 18th Century', in Biography in the 18th Century, ed. J. D. Browning, New York, 1980, pp. 28-42 (30); repeated by id., 'Suetonius', in The Classical Tradition, ed. A. Grafton et al., Cambridge MA and London, 2010, pp. 912-13 (913).
} 
end of the fifteenth century and culminating in the 1595, 1596 and 1610 editions by Casaubon, the early seventeenth century also gave rise to a new type of commentary, promising moral and political observations. $^{2}$

As was typical of the period, fifteenth- and sixteenth-century commentators on Suetonius's work often repeated Cicero's utilitarian definition of history as the teacher of life ('historia vitae magistra', De oratore, II.36), presenting his Lives as an exempla collection of virtues to be fostered and - in much larger numbers - vices to be shunned. But, the ethical emphasis of their prefaces notwithstanding, in their printed commentaries hardly any of them drew actual moral lessons from Suetonius's work. Nor was the Lives of the Twelve Caesars used for political instruction. Although earlier commentary editions were often dedicated to princes, or their advisors, as mirrors for the amendment of their own government and behaviour, none of them reflected on the ideal form of government and the ideal ruler, nor did they contain any discussion of the nature, potential and limits of the principate. ${ }^{3}$ While Tacitus and other classical authors had long been the subject of political commentary, ${ }^{4}$ it was not until the beginning of the seventeenth century that such interpretations of Suetonius found their way into print.

It is the aim of this article to show that, far from losing its influence or appeal, from the late sixteenth century onwards Suetonius's Lives of the Twelve Caesars was read in novel ways. The biographies were still consulted for information on life at the imperial court, and scholars still competed with each other in the emendation and elucidation of problematic passages. Some of them, however, took particular interest in the figure of the prince and the way in which he

\footnotetext{
2 Strikingly, Suetonius is one of the only major Latin historians still lacking an article in the Catalogus Translationum et Commentariorum. While considerable scholarly attention has been paid to the 14th- and 15th-century exegetical tradition of his Lives of the Caesars (especially to the activity of Petrarch, Domizio Calderini, Giovanni Calfurnio and Angelo Poliziano), there are very few studies on the 16th- and 17th-century printed editions of and commentaries on Suetonius's work. Notable exceptions are M. Völkel, 'Historiographische Paratexte: Anmerkungen zu den Editionen antiker Geschichtsschreiber im 16. und 17. Jahrhundert (Caesar / Sueton)', Archiv für Kulturgeschichte, 85, 2003, pp. 243-75; S. Fabrizio-Costa and F. La Brasca, 'Suetonii lectio: Le commentaire de Filippo Beroaldo l'Ancien aux Vies des douze Césars de Suétone (1493)', in Présence de Suétone: Actes du colloque tenu à Clermont-Ferrand (25-27 novembre 2004). À Michel Dubuisson in memoriam, ed. R. Poignault, Clermont-Ferrand, 2009, pp. 203-28; R. Kaiser, 'Nepos and Suetonius Meet the Early Modern Period: Some Observations on Transformations of Ancient Biographical Literature in Humanist Editions and Commentaries', in Framing Classical Reception Studies, ed. M. De Pourcq et al., Leiden, forthcoming; and M. Crab, 'Henricus Petri's Editions of Suetonius: Printing and Commenting the Lives of the Twelve Caesars in 16th-Century Basle', Viator: Medieval and Renaissance Studies, 48, 2017. On Suetonius's early modern fortuna, see also R. C. Lounsbury, The Arts of Suetonius: An Introduction, New York, 1987, pp. 27-61.

3 The only exception is Erasmus, who in the famous dedicatory letter to his 1518 edition (Ep. 586) maintained that no one is able to govern the whole world by himself, as absolute power drives men insane. Instead, he argued in favour of a unified Europe, ruled by Christian princes working together for Christ, the one true monarch. This political reading of Suetonius is not reflected in Erasmus's commentary, which focuses exclusively on linguistic usage; see Crab, 'Henricus Petri's Editions of Suetonius' (n. 2 above).

4 See, e.g., the seminal studies by G. Toffanin, Machiavelli e il 'Tacitismo': La 'politica storica' al tempo della Controriforma, Padua, 1921, repr. Naples, 1972; A. Momigliano, 'The First Political Commentary on Tacitus', Journal of Roman Studies, 37, 1947, pp. 91-101; id., 'Tacitus and the Tacitist Tradition', in The Classical Foundations of Modern Historiography, ed. R. Di Donato, Berkeley, 1990, pp. 109-31; E.-L. Etter, Tacitus in der Geistesgeschichte des 16. und 17. Jahrbunderts, Basle, 1966; P. Burke, 'Tacitism', in Tacitus, ed. T. A. Dorey, London, 1969, pp. 149-71; and K. C. Schellhase, Tacitus in Renaissance Political Thought, Chicago, 1976.
} 
governed his country. I offer case studies of four such works, which are so far little known and studied: Simon Goulart's notae morales ac politicae (Lyon 1592), Matthias Bernegger's political disputations (Strasbourg 1624, 1654), Jacobus Zevecotius's observationes politicae (Amsterdam 1630, 1637) and Johannes Boeclerus's political dissertations (Strasbourg 1647). As indicated by their titles, these texts belong to different literary genres, and, as such, there is great variation in their form and content. They were, moreover, composed in different times and places, and targeted different readerships. Therefore, the term 'political commentary' is to be understood here in its broadest sense, indicating that all four authors engaged with Suetonius's work in a political way. Exploring their respective motives and methods will illustrate the various uses to which seventeenth-century scholars put Suetonius's biographies, revealing why and how they sought to make the Lives of the Twelve Caesars relevant to their own time.

\section{Simon Goulart (1592)}

The first to break away from the historical-philological tradition of commenting on Suetonius was the French Protestant minister Simon Goulart Silvanectensis (de Senlis, 1543-1628), who, having fled his native land in 1566, served the Reformed church of Geneva as a preacher, pastor and polemicist for over fifty years. ${ }^{5}$ A prolific writer, during his long career Goulart authored, edited, translated and annotated over a hundred separate works of poetry, history, theology and devotion. Though best known as a compiler and popularizer of classical, patristic, medieval and humanist thought, his notes on Suetonius were nevertheless an original piece of work.

Goulart's edition with commentary of Suetonius's Lives of the Twelve Caesars is part of a larger collection of imperial biographies, dedicated to the French jurist Denis Godefroy. The first part of his Historia Augusta, spanning the reigns of Caesar to Domitian, was printed in Lyon by François Le Preux in 1592 and again in $1593 .{ }^{6}$ For each of the first twelve emperors of Rome, Goulart gave not only the Latin text of Suetonius, but also that of Cassius Dio's Roman History, and, wherever possible, that of Plutarch's Parallel Lives (i.e., for Caesar, Galba and Otho) and

\footnotetext{
5 There is a considerable and growing body of literature on the life and works of Simon Goulart. The standard biography is L. C. Jones, Simon Goulart 1543-1628: Étude biographique et bibliographique, Geneva and Paris, 1917, but see now also A. Graves-Monroe, 'Post tenebras lex': Preuves et propagande dans l'bistoriographie engagée de Simon Goulart (15431628), Geneva, 2012, and Simon Goulart, un pasteur aux intérêts vastes comme le monde, ed. O. Pot, Geneva, 2013, with further literature. J.-F. Gilmont's 'Annexe 1: Les impressions genevoises de Simon Goulart', which appears on pp. 471-88 in Pot's collection, is the most complete bibliography of Goulart's writings.

${ }^{6}$ Historiae Augustae tomus primus, in duas partes tributus... Ex Plutarcho, Dione, Tacito, Suetonio collectus. Acceserunt breviaria singulis libris praefixa, perpetuae ad marginem notae morales ac politicae, gnomologia historica, orationum et rerum insignium indices, ad lectorem de instituto et usu Historiae Augustae praefatio. Vol. I contains the biographies of Caesar to Nero, vol. II continues the series up to Domitian.

7 Or more precisely the epitome by Xiphilinus (11th cent.); Goulart used the Latin translation of Guillaume Leblanc, which was first printed in Paris by Robert Estienne in 1551.
} 
Tacitus's imperial histories (for Tiberius, Claudius, Nero, Galba, Otho, Vitellius and Vespasian). As was his usual practice, Goulart provided his edition with a wide range of paratextual materials, such as breviaria, notae perpetuae and a number of indices, to guide the reading and interpretation of the work. ${ }^{8}$

From these paratexts, it is apparent that Goulart set greater store by the texts' usefulness for contemporary readers than by their historic and documentary value. Admittedly, at the end of the edition there is a chronological table which lists the consuls and most important res gestae of each year. Nevertheless, Goulart admits that he did not compare divergent accounts and only included established facts. Moreover, he made sure to insert events from ecclesiastical history, so that the reader would encounter some piety in between all massacres and turmoil. ${ }^{9}$ According to the publisher, the Chronologia Augusta and adjoining indices rerum, orationum et sententiarum were added to help the readers follow the emperors' examples of virtues (especially piety, justice and moderation) and avoid the corresponding vices. ${ }^{10}$ Goulart's notae morales ac politicae, which are printed in the margins of the text, evidently served a similar purpose.

This is easily demonstrated by examining Goulart's notes on Julius Caesar, whom Suetonius considered the first emperor of Rome. Having fascinated humanists from Petrarch onwards, Caesar was well known to Goulart. Some ten years earlier, in 1583, he had published a French edition of Plutarch's Parallel Lives, including the biographies of Julius Caesar and his Greek counterpart Alexander the Great. ${ }^{11}$ While faithfully reproducing the translation of Jacques

\footnotetext{
8 So far, studies of Goulart's editorial practice have mainly focused on his French editions of Plutarch's Euvres morales es meslées (1581-1582) and Vies parallèles (1583), which will be discussed below; see J. Pineaux, 'Un continuateur des Vies parallèles: Simon Goulart de Senlis (S.G.S.)', in Fortunes de Jacques Amyot: Actes du colloque international (Melun 18-20 avril 1985), ed. M. Balard, Paris, 1986, pp. 331-42; D. Carabin, 'Comment Goulart indexe-til le Plutarque d'Amyot?', Bibliothèque d'Humanisme et Renaissance, 65.2, 2003, pp. 331-46; Graves-Monroe, 'Post tenebras lex' (n. 5 above), pp. 13-14, 41-43, 49; N. Kenny, 'Rendre commode ce qui pourroit nous nuire en beaucoup de sortes: Le détournement des textes et de la curiosité chez Simon Goulart', in Pot, Simon Goulart (n. 5 above), pp. 57-73 (59-62); and M.-D. Legrand, 'Simon Goulart éditeur de Plutarque: Exploration de ses notes et de ses commentaires à la traduction de Jacques Amyot', ibid., pp. 111-24. To the best of my knowledge, such a study has not yet been undertaken for his Latin Historia Augusta.

9 'Ad candidum lectorem', ed. 1592, II, unnumbered fol. preceding the Chronologia Augusta: 'Res Ecclesiae leviter attigimus, ut inter tot turbas et strages imperii Romani pietatis aliqua recordatio tibi occurreret.'

10 'Typographus candido lectori', ed. 1592, II, sig. * ${ }^{*}{ }^{\mathrm{r}} \mathrm{v}^{\mathrm{v}}$ : 'Chronologiam, gnomologiam, orationum et rerum indices ad finem huius partis reieci, ut ... insignia ad vitam recte instituendam documenta quae in Historiae Augustae ... exemplis occurrunt tibi inservirent, quorum summa haec est: ut superstitione, impietate, iniustitia et intemperantia reiectis ... sincera [sic] pietatis, iustitiae, temperantiae amorem induas et colas.'

${ }^{11}$ Les vies des hommes illustres grecs et romains, comparees l'une avec l'autre par Plutarque de Chaeronee. Translatees par M. Jacques Amyot Conseiller du Roy etc. ... Enrichies en ceste derniere edition d'amples sommaires sur chacune vie, d'annotations morales en marge qui monstrent le profit qu'on peut faire en la lecture de ces histoires, et de quatre indices representans les auteurs, les similitudes, les apophtegmes et les matieres remarquables en tout l'cuvre. ... Le tout disposé par S.G.S. Avec les vives effigies des hommes illustres soigneusement retirees des medailles antiques, ensemble une chronologie tres-necessaire pour l'intelligence des temps esquels ils ont vescu, [Geneva]: Jérémie des Planches, 1583. The work is discussed by Pineaux, 'Un continuateur des Vies parallèles' (n. 8 above), and Legrand, 'Simon Goulart éditeur de Plutarque' (ibid.); Pinceaux, although much more informative than Legrand, erroneously ascribed to the second 1587 edition some features already present in 1583 (e.g., the notes 'L'origine ... monarchie' and 'Harangue ... filial' quoted on p. 336 can be found in the 1583 edition on fols $11^{\mathrm{v}}$ and $\left.18^{\mathrm{v}}\right)$.
} 
Amyot, Goulart made some significant contributions of his own: for instance, he supplemented Plutarch's lost comparison between Caesar and Alexander, discussing the merits of each hero, and also added his own account of the lives of, among others, Rome's second emperor, Augustus. ${ }^{12}$ Moreover, Goulart equipped Plutarch's text with summaries, a chronological table, and no less than four different indices (auctorum, similitudinum, apophthegmatum and memorabilium); in addition, he filled its margins with copious moral annotations showing the benefit one could gain from reading such histories ('le profit qu'on peut faire en la lecture de ces histoires'). Goulart's edition proved highly successful: it was reprinted at least seventeen times before the year 1620, and translated into other vernacular languages. The additional lives were rendered into English by Thomas North in 1602 and incorporated in his edition of Plutarch in $1603 ;^{13}$ and at about the same time the Leiden University publishers Jan Paedts and Jan Bouwens printed a Dutch edition of Goulart's work, copying both the layout and the contents of the French original, including its moral annotations. ${ }^{14}$

Previously, however, Goulart himself had made a Latin version of his notes on Plutarch's Caesar, which in the 1592 edition accompany his newly produced commentaries on the lives of Julius Caesar by Suetonius and Cassius Dio. A detailed comparison of Goulart's notes on all three authors is beyond the scope of this article; but it is important to realize that in his commentary on Suetonius's Life of Julius Caesar Goulart repeated hardly any of the notes found in the margins of Plutarch's biography. Given the striking similarities in subject matter and approach, a certain degree of overlap is, of course, inevitable. Yet, since Goulart geared each set of notes to the specific text on which he was commenting, his notes on Suetonius resemble those on Plutarch far less than one might expect.

In his Life of Julius Caesar, Suetonius develops the protagonist's political career, from his earliest accomplishments to his ascent to absolute power, and eventually to his fall, assassination, funeral and apotheosis, while also discussing Caesar's appearance, life-style, love life, personality, military, administrative and literary skills, attitude to the gods and so on. While some of Goulart's notes were simply designed to help the reader locate particular passages in the text, summarizing episodes and highlighting key words, most were interpretative rather than heuristic in nature.

\footnotetext{
${ }^{12}$ Ed. 1583, fols $481^{\mathrm{r}}-485^{\mathrm{r}}$ and $752^{\mathrm{r}}-767^{\mathrm{r}}$. On Goulart's comparison of Caesar and Alexander, see Pineaux, 'Un continuateur des Vies parallèles' (n. 8 above), pp. 337-8, 340.

13 See F. Cox Jensen, Reading the Roman Republic in Early Modern England, Leiden, 2012, pp. 190-91. The 'Lives newly added' are printed following Plutarch's original biographies in the 1603 London edition printed by Richard Field; here, as in the 1602 booklet (entitled The Lives of Epaminondas, of Philip of Macedon, of Dionysius the Elder and of Octavius Caesar Augustus and printed by the same), Goulart's life of Augustus appears on pp. 51-75. In 1603 North also translated Goulart's comparison of Caesar and Alexander; see ibid. pp. 743-50.

14 See O. Van Marion, 'The Reception of Plutarch in the Netherlands: Octavia and Cleopatra in the Heroic Epistles of J. B. Wellekens (1710)', in Recreating Ancient History: Episodes from the Greek and Roman Past in the Arts and Literature of the Early Modern Period, ed. K. Enenkel et al., Leiden, 2001, pp. 213-34 (224-7).
} 
Where Suetonius had limited himself to recounting Caesar's deeds and sayings, without drawing any conclusions, Goulart passed clear moral judgements on the first emperor of Rome.

According to Goulart, Caesar definitely had some good qualities which were worthy of imitation, but his view of the man was not entirely positive. Seeking to reveal the mechanisms which Caesar used to seize and retain supreme power, Goulart portrayed him as an extremely ambitious ruler (the word ambitio, which is used only once in Suetonius's Life of Julius Caesar, occurs some sixteen times in Goulart's notes on the text), who would do anything to achieve his goal and let nothing or no one stand in his way. ${ }^{15}$ Proceeding slyly and secretly, careful not to show his true colours, he did not hesitate to act against the law and caused great sorrow by taking up arms against his own people. ${ }^{16}$ Goulart showed no more approval for Caesar's conduct in private than in civil life. While severely denouncing his hunger for glory, he also found fault with Caesar's sexual indulgence, his vanity and excessive love of luxurious goods. ${ }^{17}$ Much more laudable were his achievements as a writer ${ }^{18}$ (though Goulart immediately added that 'a prince ought to be eloquent, but first and foremost a pious, fair and good father to his people'! $)^{19}$ and, more importantly, as a military commander. ${ }^{20}$ On the battlefield, no one was braver, faster, more vigorous, persistent or clever than Caesar, and Goulart was full of praise for his military genius and the way he treated his troops. ${ }^{21}$ Summarizing, he wrote that 'Julius Caesar, master in military and political discipline, took pride of place among the pagan princes, above all on account of his martial skills and his practice of never delaying. Yet, as a paragon of vast ambition, he caused himself and his country great harm, and his death was followed by many miracles. ${ }^{22}$

The image of Caesar painted in Goulart's notes is not, admittedly, altogether novel. Staying close to his source text, listing the emperors' virtues and vices as illustrated by Suetonius and making explicit what he had only implied, Goulart did not judge the Caesars much differently from earlier commentators such as Erasmus (ed. 1518) and his successor Henricus Glareanus (ed.

\footnotetext{
15 E.g., ed. 1592, I, p. 86 (\$20): 'Quamprimum enim ambitio sedem obtinuit et septrum [sic], facessant oportet quicunque vel tantillum illi resistere cogitant.’ Ibid., p. 107 (\$59): 'Intrepidus item animus et ad omnia paratus.'

16 E.g., ed. 1592, I, p. 93 (\$30): 'Vulpinae leoninam tandem assuunt reipublicae invasores, non sine vario praetextu, quanvis nunquam iusta causa sit arma in patriam induendi.'

17 E.g., ed. 1592, I, p. 101 (\$47): 'Ingentis fortunae spuma vanitas et terrestrium nimius amor', p. 102 (\$49): 'Grave et perenne Caesaris opprobrium', and p. 103 (\$51): ‘Caesaris turpitudo execranda.'

${ }^{18}$ Ed. 1592, I, p. 106 (\$56): 'Scribat princeps, sed vera, necessaria, Reipublicae suae et posteritati utilia nominique suo convenientia.'

${ }^{19}$ Ed. 1592, I, p. 105 (\$55): 'Esto princeps eloquens, sed inprimis et ante omnia pius, iustus, pater populi.'

20 This was also the main point of Goulart's 1583 comparison of Caesar and Alexander: though leaving the final verdict to the reader, it is clear that he regarded Caesar as the better military commander but Alexander as the greater man.

21 E.g., ed. 1592, I, p. 108 (\$60): 'Occasionum sollers indagator. Non cunctator. Victoriae obtinendae et retinendae peritus magister.'

22 Quotation from Goulart's preface to the reader (ed. 1592, I, sig. *4v): 'Iulius Caesar, disciplinae militaris et politicae magister, inter ethnicos principes palmam obtinet, praesertim ob bellicas artes, quarum praecipua fuit non cunctari. Idem, ambitionis immensae exemplum, mala innumera sibi et aliis exhibet, viamque aperit ad miranda illa quae mortem eius consequuta sunt.'
} 
1560). ${ }^{23}$ What is new, however, is the way in which this image was presented. Whereas Erasmus and Glareanus had expressed their views on Suetonius's Caesars only in the prefaces to their works, which allowed readers to draw their own conclusions and lessons, in Goulart's 1592 edition there is no getting around his judgements and appreciations. The margins of the lives from Augustus to Domitian are as tightly packed with notes as that of Caesar: paragraph after paragraph and page after page, Goulart analyses the emperors' behaviour, pointing out what they got right and when they went astray. Accordingly, he not only assesses their actions, but also indicates how a ruler - in his opinion - ought to behave. Throughout his notes on Suetonius's Life of Julius Caesar, we find Goulart insisting on the importance of showing mercy in fighting civil wars, ${ }^{24}$ and teaching that a military commander should bear down on deserters and rebels, ${ }^{25}$ that a prince is best protected when loved by his subjects, ${ }^{26}$ and so on. In addition to military and political lessons, he also imparts some general moral wisdom, stating, for example, that stolid and lazy people will never achieve greatness, ${ }^{27}$ that in order to obtain one's goal one should be patient and willing to make an effort, ${ }^{28}$ and that a sensible man neither fears nor desires death. ${ }^{29}$ By guiding his readers on every step of the way, Goulart practised what previous commentators had only preached. Erasmus and his colleagues may have presented Suetonius's work as a mirror-forprinces, but Goulart actually transformed it into one.

This does not mean, however, that Goulart's edition was intended only for (future) leaders. Given its didactic approach, the book was instead designed for the general public. By the end of the sixteenth century more people were reading, and were doing so in more unsupervised contexts; so Goulart must have been anxious about new, especially younger readers potentially drawing the wrong lessons from Suetonius's text. By spelling out the 'right' politico-moral lessons, he not only showed these readers how best to approach Suetonius's narratives, but also provided them with a series of notes and commonplaces which they could then insert into their own notebooks.

${ }^{23}$ Not coincidentally, in the 1592 edition Erasmus's Iudicium de Historiae Augustae usu is printed following Goulart's own preface to the reader. As devout Christians, both Erasmus and Glareanus focused on the negative rather than the positive aspects of Suetonius's stories, describing the emperors as monsters and madmen: see Crab, 'Henricus Petri's Editions of Suetonius' (n. 2 above). But while Erasmus had allowed some exceptions, arguing that a Christian prince might well follow the example of Augustus, Titus or Vespasian, Glareanus vehemently denounced each and every one of them. In his inaugural Oratio in C. Suetonium Tranquillum, which had originally been delivered in Freiburg in 1554 and appears after Glareanus's notes in the Basle 1560 edition (pp. 58-70, esp. 61-62), he was blind to Caesar's positive qualities, hammering away at his ambition, impiety, violence, outrages, extravagance, lawlessness and so on.

${ }^{24}$ Ed. 1592, I, pp. 108-9 (\$63): 'Clementia prudens in bello civili primaria virtus.'

${ }^{25}$ Ed. 1592, I, p. 109 (\$67): 'Desertores et seditiosi milites praecipue puniendi.'

${ }^{26}$ Ed. 1592, I, p. 110 (\$68): ‘Amor subditorum tutela invicta est principum.'

${ }^{27}$ Ed. 1592 , I, p. 95 (\$34): ' ‘... nec stolidi aut segnes unquam aliquid magnum efficient.'

${ }^{28}$ Ed. 1592, I, p. 107 (\$57): 'Laboris amans et patiens necesse sit qui in vocatione (qualiscunque ea sit) aliquos progressus facere cupit.'

${ }^{29}$ Ed. 1592, I, p. 121 (§87): 'Nec metuenda nec optanda mors, qualiscunque ea sit, cordato viro est.' 
It is clear from these examples that Goulart conceived of human nature and moral lessons as universal; consequently, there are only a few references to his own time. While in his preface Goulart highlighted the similitudo temporum between imperial Rome and his own day, both of which were prey to impiety, faithlessness, cruelty and injustice, ${ }^{30}$ the actual notae morales ac politicae are not tied to a particular place or time. In his notes on Suetonius's Life of Julius Caesar Goulart alludes to the political reality of his day only twice, contrasting Caesar's gentleness and temperance with the harshness and fury of contemporary tyrants. ${ }^{31}$ Perhaps more surprising, given his position as a Protestant minister, is the lack of religious interpretation. In fact, Goulart repeatedly called Caesar 'impious' and considered his deification 'pagan, ridiculous and wicked'. ${ }^{32}$ But although in his preface he promised that some of his notes would reveal God's patience, justice and mercy, ${ }^{33}$ this seems less true for Suetonius than for Plutarch. ${ }^{34}$ Only his final note on Suetonius's Life of Julius Caesar evidences God's role in history, arguing that the Lord got rid of both Caesar and his murderers so that the Romans would learn justice and rule their empire better. $^{35}$

In conclusion, Goulart's 1592 notes on Suetonius's Lives of the Twelve Caesars represent a very different kind of commentary from the ones published before it. While Goulart was a personal friend of Casaubon's and definitely knew his commentary on Suetonius (probably in the third edition of 1603), ${ }^{36}$ he did not share Casaubon's scholarly aspirations, nor was he interested in the philological and antiquarian aspects of Suetonius's work. Instead, he sought to make the text useful for as wide a readership as possible, but first and foremost for youngsters, who could learn valuable moral and political lessons from his notes and use the indexed orationes and

${ }^{30}$ Ed. 1592, I, sig. $* 3^{\mathrm{v}}$ : $V i r t u t u m$ et vitiorum exempla in Europaeorum historiis, ab annis centum occurentia, ob oculos reponunt illas multiplicis impietatis, iniustitiae, perfidiae, crudelitatis, latrociniorum facies, quae in Historiae Augustae singulis pene paginis apparent. Illam si quis attente perlegerit, in aliena republica suam proculdubio depictam, mutatis tantum coloribus et lineis, agnoscet.'

${ }^{31}$ Ed. 1592, I, p. 113 (\$74): 'Exempla observatu digna quae tyrannorum veterum et recentiorum immanitatem damnant.' Ibid. (\$75): 'Interea vero Caesar temperantia tyrannulorum nostri seculi furores palam damnat atque profligat.' Goulart is probably referring to the Valois, who in his opinion were responsible for the St Bartholomew Day's massacre of 1572; see C. Huchard, 'Tyrans anciens et modernes dans les Mémoires de l'Estat de France de Simon Goulart', in Figures du tyran antique au Moyen Age et à la Renaissance: Caligula, Néron et les autres, ed. D. Bjaï and S. Menegaldo, Paris, 2009, pp. 189-208 (190), and S. M. Manetsch, 'Simon Goulart (1543-1628) and the Consolation of Troubled Souls', Calvin Theological Journal, 49, 2014, pp. 201-20 (207).

32 E.g., ed. 1592, I, p. 115 (\$77): 'Impium prodit animum’, and p. 122 (\$88): 'Apotheosis ethnica, ridicula et impia.'

${ }^{33}$ Ed. 1592, I, sig. $*^{\mathrm{r}-\mathrm{v}}$ : 'Notas frequentes sparsi, quae partim Summi Rerum Arbitri in mundi sapientissima administratione patientiam, iustitiam, misericordiam ... detegerent.'

34 See Pineaux, 'Un continuateur des Vies paralleles' (n. 8 above), pp. 335-40; Van Marion, 'The Reception of Plutarch' (n. 14 above), pp. 226-7; and Kenny, 'Rendre commode ce qui pourroit nous nuire' (n. 8 above), pp. 60-62.

${ }^{3}$ Ed. 1592, I, p. 122 (\$89): 'Et percussus et percussores, arcano quidem sed iusto Summi Rerum Arbitri iudicio, de medio tolluntur, ut omnes iustitiam discant, moniti, et reipublicae quam decet curam pro suae vocationis ratione sincero cordis affectu perpetuo gerant.' God's name is also invoked on pp. 92 and 94 (\$\$29 and 94).

${ }^{36}$ See Jones, Simon Goulart (n. 5 above), p. 408. 
sententiae for rhetorical purposes ${ }^{37}$ Consequently, as in his editions of Plutarch, here, too, 'Goulart nous présente ... sa version reformée de l'humanisme italien, où le savoir antique se met à la portée de l'homme du monde qui met l'éloquence et les valeurs qu'il a apprises au service du civisme. $^{38}$

\section{Matthias Bernegger $(1624,1654)$}

Noble though his ambition may have been, Goulart's 1592 notes on Suetonius seem to have found little response. Hidden in the margins of a larger collection of imperial biographies, they were not known, or in any case not cited by later commentators on the Lives of the Twelve Caesars, for whom Casaubon's 1595 edition quickly became the point of reference. As mentioned in the introduction, the next two decades saw the production of another six philological and historicalantiquarian commentaries, only one of which showed any interest in the moral and political aspects of Suetonius's stories. Like Goulart's notes on Suetonius, those of the Flemish-born classical philologist Janus Gruterus were part of a larger collection Historiae Augustae scriptores Latini minores, published by Johannes and Andreas Marnius in Hanau in 1611. Like Goulart, moreover, Gruterus, too, believed Roman history to be an inexhaustible source of knowledge of divine providence and political doctrine $;^{39}$ and in his edition all ethical and political passages from Suetonius's text were printed in italics, so that they would immediately catch the young and inexperienced readers' eye (and then be introduced into their commonplace books). ${ }^{40}$ As the accompanying notes are almost exclusively philological in nature, however, in the end Gruterus only told his audience which passages to read, without providing them with guidance on how to read them.

The next political interpretation of Suetonius was undertaken some ten years later, by one of Gruterus's colleagues and friends, Matthias Bernegger (1582-1640). ${ }^{41}$ Born in the little village

37 Quotation from Goulart's preface to the reader, ed. 1592, I, sig. *4r: 'Apud me constitutum fuit, quum Historiam Augustam colligerem, bonae spei iuvenes, proposita virtutis et vitii in tot hominibus effigie, a malis affectibus ad purae mentis studia magis ac magis revocare.' Ibid., sig. *6r: 'Id unum igitur petimus et expetimus, ut sicuti sincero animi affectu opellam hanc studiosae iuventuti navatam ad umbilicum tandem perduximus, ita quicunque ex Historiae Augustae lectione non modo doctiores, sed etiam meliores evadent, ii nobis per Christum gratiam et pacem a Deo Optimo Maximo precentur.'

38 Graves-Monroe, 'Post tenebras lex' (n. 5 above), p. 43.

39 Ed. 1611, 'Ad lectorem', sig. *6r: '... ut iam non agnoscant historias solummodo uberrimos rerum ante nos gestarum condos promos, sed et divinae providentiae, sed et doctrinae politicae inexhaustum plane oceanum.'

40 Ed. 1611, 'Ad lectorem', sig. $* 5^{\mathrm{v}}$ : 'Etiam ethica ac politica ... nonnumquam insignivimus, introducta alia tantummodo characterum specie, ut vel primo intuitu haberi queant iuventuti rudiori.'

${ }^{41}$ On Bernegger's life and works, see C. Bünger, Matthias Bernegger: Ein Bild aus dem geistigen Leben Straßburgs zur Zeit des Dreißigjährigen Krieges, Strasbourg, 1893; Etter, Tacitus (n. 4 above), pp. 154-7; E. Berneker, 'Matthias Bernegger, der Straßburger Historiker', in Julius Echter und seine Zeit, ed. F. Merzbacher, Würzburg, 1973, pp. 283-314; S. Garcia, 'Bernegger, Mathias (1582-1640)', in Centuriae Latinae II: Cent une figures bumanistes de la Renaissance aux Lumières à la 
of Hallstatt in Upper Austria, Bernegger received his first education in Wels and continued his law studies at the Academy (from 1621 onwards University) of Strasbourg. After his Protestant family was expelled from Habsburg Austria during the Counter-Reformation, he returned to Strasbourg, where he was appointed Professor of History in 1613, and between 1626 and 1629 also held the Chair of Rhetoric. On his death in 1640, Bernegger was succeeded by his pupil Johannes Boeclerus, whose own work on Suetonius will be discussed below. During his long and successful career, Bernegger was a key figure in the cultural and intellectual life of seventeenthcentury Strasbourg. While scarcely ever leaving the city, he kept up a lively correspondence with scholars from all over Europe, including Johannes Kepler, Galileo Galilei, Hugo Grotius, Daniel Heinsius and Gerardus Vossius. ${ }^{42} \mathrm{~A}$ true polyhistor, he had very wide interests, ranging from natural sciences and mathematics to astronomy. While Bernegger is probably best known for his Manuale mathematicum (1612), his polemic Tuba pacis (1621) and his Latin translations of Galileo's Operazioni del compasso geometrico et militare (1612) and Dialogo sopra i due massimi sistemi del mondo (1635), I will focus on his editions with commentaries of ancient historians, arising from his university teaching at Strasbourg.

As Professor of History, Bernegger narrowed the study of Universalgeschichte, devoting all of his time to reading the ancient historians. Following the Flemish humanist Justus Lipsius, whose Politicorum sive Civilis doctrinae libri sex (1589) enjoyed great popularity in seventeenthcentury Strasbourg, Bernegger believed that ancient history offers not only examples of moral virtues and vices, but also of political prudence (prudentia politica or, in Lipsius's words, prudentia civilis). Consequently, he, too, coupled the study of history to that of politics and read Quintus Curtius Rufus, Justin, Florus, Tacitus's Agricola and Germania, Pliny the Younger's Panegyric of Trajan and also Suetonius's Lives of the Twelve Caesars from a political perspective, paying more attention to the contents of these works than to their Latin style and drawing from them lessons useful for public life. ${ }^{43}$ Evidence of Bernegger's history classes can be found in the many

mémoire de Marie-Madeleine de la Garanderie, ed. C. Nativel, Geneva, 2006, pp. 81-6; and W. Kühlmann, 'Bernegger, Matthias', in Der Neue Pauly: Supplemente, VI, Stuttgart and Weimar, 2012, pp. 85-7.

42 There is no complete modern edition of his correspondence; for a partial one, see Briefe G. M. Lingelsheims, M. Berneggers und ibrer Freunde, ed. A. Reifferscheid, Heilbronn, 1889.

${ }^{43}$ See Bünger, Matthias Bernegger (n. 41 above), pp. 92-142, 294-331; A. Schindling, Humanistische Hochschule und freie Reichsstadt: Gymnasium und Akademie in Straßburg 1538-1621, Wiesbaden, 1977, pp. 279-89; W. Kühlmann, 'Matthias Bernegger (1582-1640) als Vertreter der politisch-historischen Philologie des Frühbarock', in id., Gelehrtenrepublik und Fürstenstaat: Entwicklung und Kritik des deutschen Späthumanismus in der Literatur des Barockzeitalters, Tübingen, 1982, pp. 43-66; and id., 'Geschichte als Gegenwart: Formen der politischen Reflexion im deutschen Tacitismus des 17. Jahrhunderts', in Res Publica Litteraria: Die Institutionen der Gelehrsamkeit in der frühen Neuzeit, ed. S. Neumeister and C. Wiedemann, 2 vols, Wiesbaden, 1987, I, pp. 325-48. The Strasbourg 'Lipsian School' is discussed by G. Oestreich, Neostoicism and the Early Modern State, ed. B. Oestreich and H. G. Koenigsberger, transl. D. McLintock, Cambridge, 1982, pp. 96-101; id., Antiker Geist und moderner Staat bei Justus Lipsius (1547-1606): Der Neustoizismus als politische Bewegung, ed. N. Mout, Göttingen, 1989, pp. 195-8; M. Stolleis, 'Lipsius-Rezeption in der politisch-juristischen Literatur des 17. Jahrhunderts in Deutschland', in id., Staat und Staatsräson in der frühen Neuzeit: Studien zur Geschichte des öffentlichen Rechts, Frankfurt am Main, 1990, pp. 232-67 (257-61); and Justus Lipsius, Politica: 
disputations defended by his students and printed at his instigation, ${ }^{44}$ as well as in the commentary editions published at his own press. Together with his former student and son-inlaw Johannes Freinsheim, from 1630 onwards Bernegger edited a number of ancient historians, adding his own commentaries as well as multiple indices. While offering little in the way of philological innovation, the editions ex typis Berneggerianis were highly praised for their didactic value. At least in this respect, Bernegger's editions resemble those of Simon Goulart.

Over the years, Bernegger taught several courses on Suetonius's Lives of the Twelves Caesars.

From his inaugural speech, it is clear that, on succeeding Kaspar Bitsch as Professor of History in 1613, Bernegger simply carried on his predecessor's lessons, ${ }^{45}$ perhaps picking up where Bitsch had left of (i.e., between Nero and Galba). ${ }^{46}$ He then read Suetonius's entire Life of Julius Caesar in 1622-1623, possibly continued with the first few chapters of Augustus straight away, discussed Titus in 1625, maybe did the same with Tiberius in 1628, lectured on Vespasian and Domitian sometime before 1630, ${ }^{47}$ and started another course on Augustus in 1632. While in 1629 Bernegger planned to comment on the remaining emperors as well, ${ }^{48}$ no materials from these lessons survive. Nor did he ever finish the complete edition of the Lives of the Twelve Caesars on which he was working in 1633, complaining that his Suetonius proceeded slowly ('satis lente Suetonius meus procedit').$^{49}$ Consequently, for more information concerning Bernegger's lectures on Suetonius we have to rely on the thirty or so disputations held by his students. These were first printed in little booklets, intended only for private use, ${ }^{50}$ and later collected under

Six Books of Politics or Political Instruction, ed. and transl. J. Waszink, Assen, 2004, pp. 194-6. As indicated by Oestreich, Antiker Geist und moderner Staat, p. 197, both Bernegger and Boeclerus taught Lipsius's Politica to their students: Bernegger's disputations on the topic were published in 1617, while Boeclerus's Dissertatio de politicis J. Lipsii accompanied Bernegger's edition of this work (ed. princeps 1641) from 1674 onwards. Interestingly, none other than Simon Goulart was responsible for the second French translation of Lipsius's Politica: see Lipsius, Politica, ed. Waszink, p. 198.

${ }^{44}$ G. Dünnhaupt, Personalbibliographien zu den Drucken des Barock, 2nd edn, 6 vols, Stuttgart, 1990-1993, I, pp. 490533 (507-33) lists some 135 disputations defended and printed under the auspices of Bernegger between 1614 and 1640 , at least 30 of which deal with Suetonius; see n. 50 below.

${ }^{45}$ Matthias Bernegger, Orationum academicarum decas, Strasbourg: Johannes Freinshemius, 1640, pp. $231-67$ (2667): 'Idque clara voce et tanquam stipulatu ultro polliceor, facturus praelectionum initium, quod Altissimus faelix et fortunatum esse iubeat, ad proximum diem lunae hora consueta tertia, et caeptas a clarissimo antecessore imperatorum vitas instituta methodo minime quidem pari dexteritate sed certe diligentia et industria non minore continuaturus.'

${ }^{46}$ See Schindling, Humanistische Hochschule (n. 43 above), p. 279 n. 30.

${ }^{47}$ Letter to Janus Gebhardus, 7 September 1630 (ed. Reifferscheid, Briefe [n. 42 above], p. 790): 'In Vespasianum inque Domitianum nescio quid publice meis auditoribus superioribus annis proposui. Verum ista lucem nec mererentur, nec expectant, cum praesertim studiosorum nemo sit, qui talibus capiatur aut ea suis sumptibus, ut in Caesare factum, excudi velit.'

${ }^{48}$ Letter to Johannes Steinberg, 12/22 July 1629 (ed. Reifferscheid, Briefe [n. 42 above], p. 790): 'In Suetonii Caesarem, Titum, Domitianum notas meas typographus recudere vellet, sed non nisi caeteris adiectis imperatoribus (id quod anno sequente cum Deo futurum spero) permittam id fieri.'

${ }^{49}$ Quotation from Bünger, Matthias Bernegger (n. 41 above), p. 328. On this edition, see also n. 142 below.

50 The first 15 Diatribae in XII Caesares, dealing with Suetonius's Life of Julius Caesar, were printed in Strasbourg by Antonius Bertramus and Hollandus Findlerus between February 1622 and September 1623. A second series of 11 Diatribae in Caesarem Augustum was printed in Strasbourg by Wilhelmus Christianus Glaser, eight of them between 
Bernegger's name in 1624 (Caesar) $^{51}$ and again, posthumously, in 1654 (Caesar, Augustus 1-36 and Titus). ${ }^{52}$

Taken together, these disputations give a good idea of Bernegger's educational practice, which he says was inspired by Philip Melanchthon. Instead of simply dictating the subject matter (ad calamum dictare), Melanchthon invited his students - even the shy and ignorant ones hiding in the back of the classroom - to participate actively, asking them questions and encouraging them to formulate their own queries. ${ }^{53}$ Similarly, Bernegger sought to increase his students' involvement in his lessons by staging diatribae or 'learned conversations'. To this end he cut the text of Suetonius's Lives of the Caesars into smaller pieces and divided these among his students for oral presentation. Each respondent, in front of the praeses and his fellow students, ${ }^{54}$ was asked to read and comment on part of Suetonius's text, while also discussing some additional questions. In the booklets on Titus (1625) and Augustus (1632-1639) there are specific quaestiones regarding the passages under discussion, while in the diatribae on Caesar (1622-1623) the text and commentary are followed by more general theses or corollaria, that is, commonplaces taken from other authors such as Seneca, Tacitus and Lipsius, which the students were expected to elaborate and assess.

What, then, was Bernegger's own contribution to these diatribae or, to put it in other words, was the commentary on Suetonius his or his students? ${ }^{55}$ On the title-pages of the individual booklets the students' names feature as prominently as that of their teacher; however,

January and July 1632, and the last three in March 1633, September 1634 and August 1639. In addition, we have an Extraordinaria diatribe on Augustus 1-8 printed by Hollandus Findlerus in 1623 [note that its contents are quite different from Johannes-Jacobus Kips's Diatribe in Caesarem Augustum 1-8 published in January 1632!]; a disputation on Suetonius's Life of Titus entitled Speculum boni principis printed by Josias Rihel in March 1625; some Conclusiones aliquot politicas ... ex Augusti Caesaris vita sub initio printed by Paulus Ledertz in November 1628; and, finally, a Decas quaestionum historico-politicarum ex Tiberii Caesaris vita sub initio printed by Johannes Reppius in 1629; see Dünnhaupt, Personalbibliographien (n. 44 above), pp. 514-7, 519, 521, 525 and 527-30, nos 69.I-XV, 75, 88, 104, 110 and 115.I-XI. As indicated in n. 47 above, Bernegger's commentaries on Vespasian and Domitian were never printed.

${ }^{51}$ C. Suetonii Tranquilli Caesar, quindecim diatribis totidem florentissimis iuvenibus, bumaniorum literarum studiosis, explicatus in Universitate Argentoratensi moderante Matthia Berneggero, Historiarum in ea Professore publico, Strasbourg: Antonius Bertramus, 1624: not listed by Dünnhaupt, Personalbibliographien (n. 44 above), but preserved in Leipzig, Universitätsbibliothek, sign. 49-8-3271.

${ }^{52}$ Matthias Bernegger, Diatribae in C. Suetonii Tranquilli C. Jul. Caesarem, Augusti quaedam et Titum Vespasianum. Ex auctoris adnotationibus passim auctae et emendatae, Strasbourg: typis Berneggerianis, 1654; repr. Strasbourg: Johannes Bockenhofferus, 1655; see Dünnhaupt, Personalbibliographien (n. 44 above), p. 504, nos 46.I-II. On the collected volumes of 1624 and 1654, see also Reifferscheid, Briefe (n. 42 above), pp. 789-90.

${ }^{53}$ See Bernegger's letter of 26 March 1625 to the Tübingen Professor Wilhelm Schickard, which in the 1654 and 1655 editions precedes the Speculum boni principis; the letter is partly edited by Reifferscheid, Briefe (n. 42 above), pp. 862-3, and translated into German by Bünger, Matthias Bernegger (n. 41 above), pp. 296-7. Further reflection on Bernegger's educational practice is found in his letter to the reader prefacing Kips's Diatribe in Caesarem Augustum 1-8 (1632).

${ }^{54}$ As was traditional, the commilitones contributed laudatory poems. It is unclear, however, whether any opponents were present at the public examination, and the same goes for the respondent's patrons, to whom the booklets were usually dedicated.

${ }_{55}$ The authorship of such disputations is often problematic; see J. F. Freedman, 'Published Academic Disputations in the Context of Other Information Formats Utilized Primarily in Central Europe (c.1550-c.1700)', in Disputatio 1200-1800: Form, Funktion und Wirkung eines Leitmediums universitärer Wissenskultur, ed. M. Gindhart and U. Kundert, Berlin, 2010, pp. 89-128 (109-10). 
in 1654 the diatribae were printed under Bernegger's name alone, and he on several occasions testified to writing the notes himself. ${ }^{56}$ Given this, and considering that all of the commentaries are (a) at an advanced level and (b) very similar in form and content, I would suggest that Bernegger was responsible for the subject matter, providing his students with the relevant information and answering their queries. ${ }^{57}$ So, even if the notes really were compiled by his students, Bernegger can still be considered their author.

As was mentioned above, Bernegger read ancient history with an eye to political prudence, teaching his students about the duties and qualities of good rulers. Since he presented Suetonius's Life of Titus as a Speculum boni principis, ${ }^{58}$ and had his students' Diatribae in Caesarem Augustum printed along with excerpts from the Tübingen law professor Christophorus Besoldus's Synopsis politicae doctrinae (1623), ${ }^{59}$ it would seem that this was also the case for Bernegger's lectures on Suetonius. A closer look at the commentaries arising from these lessons, however, reveals that his interest in the text was as much philological and historical as ethical and political. How then did he make Suetonius's Lives relevant to his own time?

To begin with, it should be noted that Bernegger was very apologetic about his work. He repeatedly stressed that his commentaries on Suetonius were not worthy of publication, ${ }^{60}$ and he stated that, coming after so many illustrious commentators, it was difficult to add anything new, since commenting on Suetonius after the incomparable Isaac Casaubon was like writing the Iliad after Homer. ${ }^{61}$ He therefore adopted the main points of the commentaries of Filippo Beroaldo the Elder, Laevinus Torrentius and Casaubon, while also discussing some elements which his predecessors had not deigned to consider. ${ }^{62}$ Echoing Lipsius's elogium of Suetonius, ${ }^{63}$ which is printed at the beginning of Johannes-Jacobus Kips's Diatribe in Caesarem Augustum 1-8 (1632), in his own preface to this edition Bernegger, too, recommended Suetonius for the purity of his

\footnotetext{
${ }^{56}$ See n. 48 above ('meas notas'), and Bernegger's preface to the Speculum boni principis (ed. 1654, sig. a2r): 'Sunt ad Suetonii Titum animadversiunculae seu notae... Aliquot non septimanae, sed menses abierunt ex quo conscribere illas aggressus sum. Et tamen si quicquid huic operae temporis est impensum in unum contraxero, non multo plus hebdomade redegero. Nec $\alpha \mu \beta 0 \lambda \iota \varepsilon \varrho \gamma$ í cessatum fuit aut negligentia, sed quod subinde per transversum obiectae nescio quae occupationes in alia distrahebant.'

57 See Bünger, Matthias Bernegger (n. 41 above), pp. 126, 298, and W. Kühlmann and W. Schäfer, Frühbarocke Stadtkultur am Oberrbein: Studien zum literarischen Werdegang J. M. Moscheroschs (1601-1669), Berlin, 1983, p. 38.

58 See n. 50 above.

${ }^{59}$ See Christoph Besold: Synopse der Politik, ed. L. Boehm, transl. C. Cosmann, Frankfurt am Main, 2000.

${ }^{60}$ See Reifferscheid, Briefe (n. 42 above), pp. 789-90.

${ }^{61}$ Ed. 1654, preface to the Speculum boni principis, sig. a2 ${ }^{\mathrm{r}}$ : 'Erunt forte qui dicent Iliada scribere post Homerum, qui post incomparabilem illum Casaubonum aliquid moliar ad Suetonium. Et sane difficile queat videri post tantum literarum et omnis eruditionis principem ad hunc auctorem illustrandum aliquid adiicere. Ego vero hoc mihi non sumo ut adferam ab eo non visa nec animadversa (quid enim aquilinam viri potuisset aciem fugere?) sed neglecta solum et insuper habita. Nam aquila, ut est in proverbio [see Erasmus, Adages, III.2.65], non captat muscas.'

${ }^{62}$ Ed. 1632, preface to Kips's Diatribe in Caesarem Augustum 1-8: 'Eo fine non solum ex iis quae Beroaldus, Torrentius, Casaubonus, aetatis superioris in hac humanitatis palaestra Milones quidam ut ita dixerim, in Suetonium ex professo sunt commentati $\tau \dot{\alpha} \kappa \alpha \iota t \omega ́ \tau \varepsilon \varrho \alpha$ delegimus, sed et captui discentium consulentes ad minutiora nonnulla, quae magni isti viri dedignati sunt attingere, descendimus.'

${ }^{63}$ Lipsius, Electa, II.17.
} 
Latin style and the invaluable knowledge of Roman antiquity to be culled from his writings, declaring that the main aim of his Diatribae was to render Suetonius's text as explicit as possible. ${ }^{64}$

As a result, the opening lines of Bernegger's notes resembles those of a typical school commentary. His Diatribae in XII Caesares starts with the traditional accessus ad auctorem, recounting Suetonius's life and works and discussing the division of his Lives into books (twelve according to the manuscripts and printed editions, but eight according to Casaubon).$^{65}$ Each paragraph of Suetonius's text is then followed by a commentary, with the lemmata keyed to the source text by means of capital letters. Following Casaubon, Bernegger's first notes on Suetonius's Life of Julius Caesar deal with its supposedly missing beginning and the etymology of Caesar's name; ${ }^{66}$ and one need not read much further to realize that his commentary, with its focus on philological issues, sits firmly within the existing exegetical tradition of Suetonius. Though rarely touching on points of grammar, rhetoric and style, Bernegger provided his students with explanations of words (mostly technical terms, but also more basic vocabulary such as 'vir praetorius $=$ praetor'), while also giving ample background information on contextual issues such as points of history, geography, and ancient customs and institutions; in the process he cited an impressive range of classical as well as contemporary authors. ${ }^{67}$ Moreover, as he stated in the preface to his Speculum boni principis, since learned men called criticism 'the sun and salt of letters' (sol et sal literarum), he also paid attention to textual and historical problems raised by previous commentators such as Filippo Beroaldo the Elder, Juan Luis Vives, Laevinus Torrentius, Adrien Turnèbe, Isaac Casaubon, Théodore Marcile and Janus Gruterus. ${ }^{68}$

Throughout his notes, however, Bernegger did more than explain Suetonius's Lives within their original cultural-historical context. Unlike his immediate predecessors, he also sought to establish political precepts, ${ }^{69}$ and he seized on particular passages to reflect on issues which were as relevant in his own day as in Suetonius's. While some of the quaestiones on Titus and Augustus deal with historical-philological matters, asking, for example, 'what kind of clothing is a

${ }^{64}$ Ed. 1632, 'Ad lectorem': 'Hae diatribae nostrae Suetonianae, ne nescius sis, id praecipue si non unice spectant, ut autorem, quo vix alius magis et linguae Latinae puritatem et antiquitatis Romanae cognitionem instillare tractanti potest, academicae iuventuti familiarissimum explicatissimum reddamus.'

65 Ad titulum (ed. 1654, pp. 1-2).

${ }^{66}$ Ad Caes. 1 (ed. 1654, p. 3).

${ }^{67}$ For a sample and further analysis of Bernegger's commentaries, see Bünger, Matthias Bernegger (n. 41 above), pp. 296-304 (esp. 301-2); Schindling, Humanistische Hochschule (n. 43 above), p. 285; and Kühlmann and Schäfer, Frübbarocke Stadtkultur (n. 57 above), pp. 37-45.

68 Reifferscheid, Briefe (n. 42 above), p. 863: '... et quia criticen ut ludum aliquem nugarum atque grammatici commatis argutias aspernantur aliqui delicatiores, quae magnorum tamen virorum iudicio sol et sal literarum est, etiam hoc genus nonnulla pro re et copia adieci.' As mentioned above, Gruterus and Bernegger knew and valued each other's commentaries on Suetonius; see ibid. p. 125 11. 48-51, p. 140 11. 22-5 and p. 173 11. 10-14.

${ }^{69}$ Ad Caes. 40 (ed. 1654, p. 87): 'Nos, quibus in evolvendi Suetonio politica praecepta sectari propositum inprimis est, id hoc loco consideremus, rectene Caesar...' 
paludamentum, and where does the word come from' or which of two or more readings is better, ${ }^{70}$ many more concern moral, political, military and legal affairs. The topics covered are as diverse as those discussed by Suetonius, including - for Bernegger's eleven Diatribae in Suetonium Augustum the qualities of rulers and military commanders (e.g., 'whether justice and bravery are a prince's best virtues', 'whether generals should participate in battle themselves', 'whether a good general ever acts rashly'); $;^{71}$ the best way to govern a state (e.g., 'whether foreigners should be treated as citizens', 'whether magistrates should serve for one or more years'); ${ }^{72}$ the best way to wage war (e.g., 'whether smaller or bigger ships are more useful', 'whether a winter break is advisable', 'whether the presence of women should be allowed in the army'); ${ }^{73}$ disciplinary measures (e.g., 'whether desertion is a capital offence', 'whether shameful or painful forms of punishment are more effective in soldiers', 'whether someone who hides an outlaw should be punished in the same way as the offender'); ${ }^{74}$ and all sorts of ethical dilemmas (e.g., 'whether it is justifiable to kill for fun', 'whether torture is an acceptable way of finding out the truth', 'whether auto-mutilation is ever permitted'). ${ }^{75}$ Occasionally the students were asked to judge specific historical situations, such as 'whether Cleopatra rightly preferred death to enslavement', or 'whether it was wise of Augustus to dismiss an entire legion in disgrace. ${ }^{76}$ Usually, however, the questions were formulated in more general terms and so, it appears, were the answers.

Unfortunately, neither the responses of the students to these quaestiones or to the corollaria are preserved, and not all of the questions listed above were treated in the commentary. There, Bernegger was mainly concerned with the historical aspects of the questions, explaining, for example, that it was unusual for women to accompany their husbands in war until the reign of Augustus, who also revived the ancient practice of sentencing deserters to death. ${ }^{77}$ Although in his commentary on the Life of Julius Caesar Bernegger regularly compared ancient customs and

${ }^{70}$ II.7 (ad Aug. 10): 'Propraetor, proconsul an vero propraetore, proconsule dicendum?’; II.8 (ad Aug. 10): 'Quod vestimenti genus, et unde dictum paludamentum?'

${ }^{71}$ I.14 (ad $A$ g. 3): 'Iustitia et fortitudo, an vero quae aliae, principes sint in viro principe virtutes?'; II.10 (ad Aug. 10): 'An ducis boni sit militis etiam officio fungi ipsumque proeliari?'; VII.34 (ad Aug. 25): 'An quo casu festinatio temeritasque perfecto duci conveniat?'

${ }^{72}$ I.5 (ad Aug. 2): 'Peregrinis an et quatenus dandus in republica locus?'; I.11 (ad Aug. 3): 'Magistratus annui an perpetui sint probabiliores?'; VIII.2 (ad Aug. 26): 'Perpetuus an anniversarius magistratus, uter ex usu magis?'

${ }^{73}$ V.7 (ad Aug. 17): 'Navesne magnae an minores utiliores bello?'; VII.5 (ad Aug. 24): 'Num hibernis mensibus intermittendum bellum?'; VII.6 (ad Aug. 24): 'An ferendus in militia comitatus muliebris?'

74 VII.16 (ad Aug. 24): 'Stationem deserere num animadversione capitali puniendum?’; VII.19 (ad Aug. 24): 'Utrum poenae genus magis proficiat apud vulgus militum, quod plus ignominiae an quod plus doloris habet?'; VIII.19 (ad Aug. 27): 'Qui proscriptum celat an pari cum eo poena afficiendus?'

75 II.5 (ad Aug. 10): 'Ludi Romanorum, quibus oblectamenti causa necati plurimi hominum, an excusari aliqua ratione defendive possint?'; V.30 (ad Aug. 19): 'An quaestionibus atque tormentis exquirenda veritas?'; VII.7 (ad $A$ g. 24): 'Seipsum admutilare an qua causa liceat?'

${ }^{76}$ V.9 (ad Aug. 17): 'Factum Cleopatrae num probandum, quod morsu aspidis interire maluit quam triumphari?'; VII.11 (ad Aug. 24): 'Prudenterne fecerit Augustus totam legionem cum ignominia dimittendo?'

77 Ad Aug. 24 (ed. 1654, pp. 113-14, 118). 
institutions to those of his own time, ${ }^{78}$ suggesting that in some respects life was better then than now ${ }^{79}$ he kept conspicuously silent on the present political situation, nor did he express any personal views. Instead, Bernegger stitched together sententiae from a wide range of classical and contemporary authors and offered ample historical examples and counterexamples, which his students could use to discuss an issue from different angles (quoting, for instance, both Sallust's appraisal of Catilina as an energetic soldier and exemplary leader, and Onosander's opinion, in his Strategikos, that commanders should not fight). ${ }^{80}$ Only occasionally did he indicate which stand to take (arguing, for example, that smaller ships are definitely more useful than bigger ones, since they are faster and more manoeuvrable, and that good princes and generals never act rashly). ${ }^{81}$ So all in all, the procedure which Bernegger's students were expected to follow in discussing the quaestiones and corollaria to Suetonius was probably not that different from his own Observationes bistorico-politicae (posthumously printed in 1656), for which Lipsius's Politica served both as a model and as a source. ${ }^{82}$ Even more germane to the case at hand is the Decas quaestionum historicopoliticarum ex Tiberii Caesaris vita sub initio depromta, quam ... ductu Matthiae Berneggeri ... publicae disquisitioni subiicit Andreas Newmann, which was printed in Strasbourg by Johannes Reppius in 1629. Unlike the diatribae discussed so far, this disputation does not contain the full text of Suetonius's Life of Tiberius, nor a commentary on his work. In it, however, we can read the responses of Bernegger's student to issues raised by Suetonius's text such as 'should foreigners be counted as citizens?', 'is it allowed to rise up against tyrants?', and 'is hereditary succession better than election? ${ }^{83}$ In order to answer such burning questions, Newmann, like Bernegger, Lipsius and others before him, fell back on the writings of antiquity, gathering loci communes without always reaching a clear-cut conclusion.

It should be clear by now that in his Diatribae in XII Caesares Bernegger adopted two different, yet complementary, approaches to Suetonius's text. On account of their historical-

\footnotetext{
${ }^{78}$ E.g., ad Caes. 40 (ed. 1654, pp. 85-6) Protestant opposition to the Gregorian calendar is cited as evidence that in Bernegger's day calendar reform was still regarded as the responsibility of the state, not of the Church; ad Caes. 43 (ibid., p. 100) he notes that in 17th-century Strasbourg, as in antiquity, there was a different dress code for plebeians and patricians; and ad Caes. 52 (ibid., p. 118) he comments that a magnate's illegitimate children were still called after their father.

${ }^{79}$ E.g., ad Caes. 43 (ed. 1654, pp. 99-100), Bernegger approved of ancient sumptuary laws, calling them an 'institutum egregium et in usum hodie revocandum', and ad Caes. 52 (ibid., p. 119) he wished that his contemporaries were as chaste as the ancient Germans.

${ }^{80}$ Ad Aug. 10 (ed. 1654, p. 42).

81 Ad Aug. 17 (ed. 1654, pp. 77-8) and 25 (ibid., pp. 127-8).

82 On Bernegger's Observationes, see Bünger, Matthias Bernegger (n. 41 above), pp. 306-15. Other precursors were Bernegger's colleague Melchior Junius, whose Quaestiones politicae appeared in 1602, and Janus Gruterus, whose Discursus politici in C. Cornelium Tacitum was first printed in 1604; see Etter, Tacitus (n. 4 above), pp. 154, 162, and Schindling, Humanistische Hochschule (n. 43 above), pp. 282, 288-9.

83 Ed. 1629, Quaest. 1 (ad Tib. 1): 'An peregrini recipiendi in numerum civium?'; Quaest. 3 (ad Tib. 4): 'An in tyrannos insurgere liceat?'; Quaest. 6 (ad Tib. 15): 'An successio praeferenda electioni?’ Note that the first question also appears ad Aug. 2 (see n. 72 above), and the second also ad Tacitum, Agricola, XV.2 and XXX.5 (see Kühlmann, 'Matthias Bernegger' [n. 43 above], p. 65 n. 154).
} 
antiquarian content and critical-philological method, Bernegger's notes on Suetonius were in line with those of earlier commentators such as Torrentius and Casaubon (or, to be more precise, he drew heavily on their works). On the other hand, the accompanying quaestiones and corollaria show that, unlike them, Bernegger also read the Lives of the Twelve Caesars from a political perspective. Although his diatribe on Titus was presented as a mirror-for-princes, and the work opens with a quotation from Pliny's Panegyric emphasizing the importance of exempla, ${ }^{84}$ Suetonius's Lives were no longer considered a simple catalogue of virtues to follow and vices to avoid, as they had been in the long sixteenth century - and, in fact, still were by Goulart. While Bernegger occasionally passed judgement on individual emperors, ${ }^{85}$ this was not the main aim of his work. Inspired by Lipsius and his followers, he used Suetonius's text instead to discuss broader moral, political, legal and military issues which were as important in seventeenth-century Germany as they had been in imperial Rome. While the questions themselves were straightforward, the answers were not. Far from extrapolating issues and applying them to his own time or imposing his personal opinions, Bernegger provided his students with ample historical examples and maxims taken from ancient writers, which could be used to argue in utramque partem. So even if Simon Goulart, Janus Gruterus and Matthias Bernegger created three very different editions of Suetonius, ultimately they all worked within the same, typically humanist tradition of mining classical texts for useful quotations and ideas. Not surprisingly, then, the questions asked and lessons taught in their works are reminiscent of the notes and commonplaces which readers had drawn from Suetonius and other ancient historians throughout the early modern period. It was not until the early seventeenth century, however, that such moral and political readings of the Lives of the Twelve Caesars were deliberately written down and committed to print.

\section{Jacobus Zevecotius $(1630,1637)$}

A third exponent of this tradition was Bernegger's contemporary Jacobus Zevecotius, who was also a Professor of History and Eloquence but who lived and worked in a very different milieu. ${ }^{86}$

\footnotetext{
${ }^{84}$ Pliny the Younger, Panegyricus, 45: 'Vita principis censura est, eaque perpetua: ad hanc dirigimur, ad hanc convertimur, nec tam imperio nobis opus est quam exemplo. Quippe infidelis recti magister est metus. Melius homines exemplis docentur, quae in primis hoc in se boni habent, quod approbant, quae praecipiunt, fieri posse.' The first sentence also appears on the title-page of the Extraordinaria diatribe printed in 1623 (see n. 50 above).

85 See, e.g., his note ad Caes. 43 (ed. 1654, pp. 97-8), where Bernegger approves of the jurisdiction of Caesar, Augustus, Claudius, Galba and Domitian, repeating Pliny's saying that even bad emperors have good qualities (Panegyricus, 56); or his note ad Caes. 57 (ibid., p. 135), in which he praises Caesar's military skills and wishes these were also present in the leaders responsible for the safety and freedom of his own country.

86 On Zevecotius's life and works, see O. Dambre, 'Van Zevecote, Jacob', in Nationaal biografisch woordenboek, IV, Brussels, 1970, cols 987-96, with further bibliography. The following titles should be added: J. IJsewijn, 'Jacobus Zevecotius, Maria Stuarta / Maria Graeca, tragoedia: A Synoptic Edition of the Five Extant Versions', Humanistica Lovaniensia, 22, 1973, pp. 256-319 (258-68); K. Porteman, 'Met nieune Nederduytsche dichten, synde van anderen sin, vertoont.
} 
Born in Ghent in 1596, Zevecotius first attended the local Augustinian school (newly founded in 1609) and then studied law in Leuven. On meeting his illustrious relative Daniel Heinsius in 1612, he sought access to the larger respublica litterarum and subsequently travelled to Italy in 1616, where he became acquainted with, among others, Scipione Borghese and Maffei Barberini (the future Pope Urban VIII). Having returned to the Southern Netherlands, Zevecotius joined the Augustinian Hermits in 1619 and was ordained a priest in the following year; but whether he felt misunderstood as a poet or found the Spanish yoke increasingly difficult to bear, five years later he abandoned the order and emigrated to the Protestant city of Leiden. From 1626 until his death in 1642, he taught History and Eloquence at the Veluwsche Gymnasium in Harderwijk. Zevecotius's literary output was written partly in Latin and partly in Dutch. Best known for his poetry, emblems and historical-political dramas, his prose works have been almost completely forgotten: as far as I am aware, his Observationes politicae on Suetonius and Florus $(1633,1638)$ have never been studied.

Zevecotius's observations on Suetonius were first printed in Amsterdam by Johannes Janssonius in 1630 and again in 1637. The 1637 edition is not, however, a simple reprint of the earlier one: having run out of copies to sell, Janssonius asked Zevecotius to revise, correct and enlarge his work. ${ }^{87}$ Zevecotius complied with his publisher's wishes, attaching some new paratexts (a new dedicatory letter and an additional letter on the correct study of politics) and substantially developing the 1630 edition: no observations are left out, but some twenty notes have been added, and many of the existing ones are expanded.

Zevecotius's work on Suetonius differs from those of Goulart and Bernegger in at least three respects. First, Zevecotius does not deal with all of Suetonius's biographies but limits himself to the Life of Julius Caesar. Second, he does not treat the complete Life of Julius Caesar but in his 143 Observata politica pays attention only to Caesar as politician and military commander, showing no interest in Caesar the writer or the man - there are hardly any notes on $\iint 45-53$, which discuss Caesar's appearance, clothing, character and love life, nor on $\$ \$ 79-89$, discussing his death, funeral and deification. And, finally, neither the 1630 nor the 1637 edition includes the text of Suetonius, so that the reader is presented solely with his observations. Zevecotius argued that it was unnecessary to reprint the full text, since Suetonius's Lives circulated widely; moreover,

Jacob van Zevecote en de Emblemata van Florentius Schoonhoven', Verslagen en Mededelingen van de Koninklijke Academie voor Nederlandse Taal- en Letterkunde, 110, 2000, pp. 1-94; and A. Visser, 'Nuchtere lessen voor het dagelijks leven: Jacob van Zevecote, Emblemata ofte sinnebeelden (1638)', in Papieren pracht uit de Amsterdamse Gouden Eeuw: Geschenken van het Dr Th. J. Steenbergen Fonds, Amsterdam, 2011, pp. 46-51. I am grateful to James A. Parente, Jr. (University of Minnesota) for sending me his paper on 'The Tragedy of Queenship: The Historical Dramas of Jacob Zevecotius', presented at the 16th Congress of the International Association for Neo-Latin Studies in Vienna, 2-7 August 2015.

${ }^{87}$ Ed. 1637, 'Ad lectorem', sig. †4v: 'Cur autem iterum haec prodeant solus in causa est typographus, qui, cum nulla sibi amplius exemplaria restare affirmaret, facile me permovit ut ea iterum reviderem, corrigerem et augerem.' 
including only the lemmata would make the volume cheaper to buy and easier to carry around. ${ }^{88}$ Practical reasons aside, however, this gave Zevecotius's work a much more independent character, showing that he conceived of his political observations, not as a 'marginal' commentary on Suetonius, but rather as an original piece of work.

This is confirmed by taking a closer look at the notes themselves. Although Zevecotius's work on Suetonius, like Bernegger's, stemmed from his teaching, ${ }^{89}$ he did not aim to explain, expand or emend the Life of Julius Caesar. Throughout his observations, Zevecotius was not particularly concerned with literary aspects of Suetonius's work, nor even with the historical Caesar. Instead, he used Suetonius's text (which thus served as 'pretext' rather than 'source text') to develop his own ideas on the government and preservation of the state - as is clearly suggested by the title Observata politica ad C. Suetonii Tranquilli Iulium Caesarem. Again, the topics of Zevecotius's notes are as diverse as the material presented by Suetonius. On $₫ 1$, which treats of Caesar's prior engagement to Cossutia, a lady of only equestrian rank but very wealthy, Zevecotius discusses the advantages and disadvantages of matrimony between people from different classes and, noting that Caesar's subsequent marriage to Cornelia was opposed by the dictator Sulla, argues that no citizen should ever be allowed to marry a public enemy or rebel, so as not to undermine state sovereignty. ${ }^{90}$ On $\$ 2$, which concerns Caesar's first campaigns, Zevecotius stresses the necessity of military service; and on $\$ 3$, when Suetonius recalls how Caesar on learning of the death of Sulla hurriedly returned to Rome, he elaborates on the need to wait for the right moment. ${ }^{91}$ On $₫ 4$, Zevecotius seizes on Caesar's charge of extortion against Dolabella to expound the need for just government and obedience to the law; and in the following pages he emphasizes the importance of eloquence in military commanders, highlights the significance of naval supremacy, points out the dangers involved in using mercenary troops and advises against conferring public offices on people who are unhappy with the constitution. ${ }^{92}$

So, like Bernegger, Zevecotius coupled the study of history to that of politics, discussing military, political and legal issues raised by Suetonius's text. But while both university professors asked similar questions, their answers were rather different. As Bernegger had done, Zevecotius displayed a thorough knowledge of ancient literature, while also citing medieval and

\footnotetext{
${ }^{88}$ Ed. 1637, 'Ad lectorem', sig. $\dagger^{\mathrm{r}-\mathrm{v}}$ : 'Non est quod mireris, amice lector, me in observatorum horum editione charactere tam exiguo formaque tam parvi uti voluisse. Quotidie video libellos illos omnibus esse gratiores, tum quia facilius eorum est pretium, tum quia nulla mole turgentes pro cuiusque itineris sociis absque difficultate possunt assumi... Suetonii verba, quae materiam mihi suggessere, ubique praeposui; omisi reliqua quae de Caesaris vita fusius ille scribit, quia is autor in omnium paene manibus est.'

${ }^{9}$ Ed. 1630, Dedication to the Tetrarchiae Velavicae deputati, sig. ***2v: 'Sed quia hoc opusculum, nisi vos me ad publicam cathedram vocassetis nec editum unquam fuisset nec compositum, vestro praesidio indigere putavi...'

${ }^{90}$ Ed. 1637, pp. 1-4.

${ }^{91}$ Ed. 1637, pp. 4-7

${ }^{2}$ Ed. 1637, pp. 7-16.
} 
contemporary historians. ${ }^{93}$ In his Observata politica, however, sententiae and exempla served another purpose from that of Bernegger's Diatribae. Whereas Bernegger had simply collected quotations, sometimes illustrating different positions and never stating his own opinion, Zevecotius used well-chosen sentences and examples to substantiate his personal points of view. Interestingly, he not only supported his observations with references to classical antiquity but also referred to contemporary events in the Netherlands, which at the time was still at war with Spain, and adduced many examples from French, German, Italian, Spanish, Swedish and Polish history as well. Military and political leaders such as Charles V and Maurice of Nassau are therefore mentioned side by side with, for example, Pericles and Alexander the Great.

In his last note on $₫ 4$ ('auxiliisque contractis'), ${ }^{94}$ to cite just one instance, Zevecotius shares the concern of summi politici about using mercenary soldiers. When a country's welfare is dependent on others, he argues, it is neither safe nor mighty, for people do not act out of altruism. There is a risk that those called to rescue will either annex the territory they helped defend (as happened to the Britons, who invited the Saxons to come and help them against the Scots and Picts) or bring the country under their own rule (as happened with the Germans, who were invited to help the Gauls but according to Tacitus enslaved them all). ${ }^{95}$ Citing Justin and Curtius Rufus, ${ }^{96}$ Zevecotius insists that mercenaries are less motivated than native soldiers, as it is booty, not victory, they are after. Moreover, mercenary soldiers come with little if any military experience, they are disloyal and difficult to control, and they easily desert to the enemy (as happened with the Swiss, who were supposed to help François I invade Italy in 1515 yet were happy to take a bribe from Pope Julius II). For all these reasons, Zevecotius thinks that it is better for a country to be defended by native young men - unless, of course, they are unhappy with the constitution and want a change of policy (as happened with the Medici in Florence), in which case mercenary troops are preferable after all. In any case, when employing mercenary soldiers, one should take care to use as few of them as possible, to mix them with native soldiers, to pick soldiers who have the reputation of being loyal and share one's hatred for the enemy, and to pay their wages punctually, so as not to end up like the Carthaginians, who, as Polybius demonstrated, became involved in a dangerous war with their former allies. ${ }^{97}$

This example shows that Zevecotius's essays are much more practical and topical than Bernegger's Diatribae, so that Gerardus Vossius rightly stated in his liminary poem: 'Zevecotius

\footnotetext{
93 The classical authors most frequently cited are Tacitus, Aristotle, Cicero, Suetonius himself, Sallust, Seneca, Cassius Dio, Curtius Rufus, Florus and Thucydides; later historians include Jean Froissart, Francesco Guicciardini and Jacques-Auguste de Thou.

${ }_{94}$ Ed. 1637, pp. 12-15.

95 Tacitus, Histories, IV.73.

96 Justinus, V.2; Curtius Rufus, III.4.

${ }_{97}$ Polybius, I.65.
} 
skilfully adapted past events to his own time. ${ }^{98}$ Moreover, as Zevecotius held very strong views about how states should be ruled and how rulers should behave, his notes have a normative character. It is true that in his Epistola de studio politico recte instituendo Zevecotius essentially followed Bernegger's method, advising the young Rudolphus van Ommeren to search ancient authors such as Aristotle, Cassius Dio, Sallust, Xenophon and Tacitus for useful examples and sentences to be collected in commonplace books; $;{ }^{99}$ however, in his observations on Suetonius's Life of Julius Caesar political instruction took on a different form. Consequently, the work qualifies as a political handbook rather than a commentary on Suetonius.

We might wonder, then, why Zevecotius chose to lecture on Suetonius in the first place. Possibly he was inspired to do so by his patron Petrus Cunaeus, who taught Law and Politics at Leiden University from 1614 until his death in 1638 and in this capacity also commented on Suetonius. ${ }^{100}$ As far as I know, Cunaeus's lectures on Caesar, Augustus and Galba are not extant; but from his inaugural speeches it can be gathered that he, too, read Suetonius's Life of Galba from a political perspective. ${ }^{101}$ In addition, Zevecotius himself explains his choice of Suetonius in the lengthy Oratio ab auctore habita cum Suetonium expositurus esset which follows his observations in the 1630 and 1637 editions. Contrary to what one might expect, this speech is a paean, not to politics, but to rhetoric and eloquence, which he claims are indispensable for those seeking to protect and preserve the state. Again, ancient models of eloquent leaders such as Odysseus, Nestor and Demosthenes sit side by side with modern examples: were it not for the oratorical gifts of William I of Orange, the Dutch Republic could not have resisted Spanish oppression; ${ }^{102}$ and Zevecotius ends his speech by exhorting his students to devote their best years to the study of eloquentia and prudentia, so that they can in turn serve their country. ${ }^{103}$ The study of eloquence (and politics) is, however, inextricably bound up with that of history, for 'history without eloquence is mute, just as eloquence without history is untutored.' For this reason, Zevecotius

\footnotetext{
${ }^{98}$ Ed. 1637, sig. A2v: 'Haec referat nobis Zevecotius, actaque / quondam docte aptat nostris singula temporibus.'

99 Ed. 1637, sigs $+5^{\mathrm{r}}-6^{\mathrm{v}}$. The same method was advocated by Lipsius in his famous letter to Nicolas de Hacqueville; see Justus Lipsius, Epistolae, pars XIII: 1600, ed. J. Papy, Brussels, 2000, pp. 316-25 (Ep. 001203 H).

${ }^{100}$ H. Wansink, Politieke wetenschappen aan de Leidse universiteit 1575-ca. 1650, Utrecht, 1981, pp. 90-1.

101 Petrus Cunaeus, Orationes varii argumenti, Leiden: ex officina Isaaci Commelini, 1640, pp. 108-32 (122): '... sed per certa intervalla ex historiis, solito more nostro, ea excuteremus quae civili doctrina convenire maxime viderentur.' Marcus Boxhorn-Zuerius, on the other hand, who obtained the Leiden Chair of Eloquence in 1632 and belonged to the same historical-political school as Zevecotius, in the year of his appointment produced a purely philological commentary on Suetonius and in 1643 did the same for Tacitus; see Wansink, Politieke wetenschappen (n. 100 above), pp. 93-107, and, for a more positive assessment, J. Nieuwstraten, 'Historical and Political Thought in the 17thCentury Dutch Republic: The Case of Marcus Zuerius Boxhorn (1612-1653)', PhD diss., Erasmus University Rotterdam, 2012.

102 Ed. 1637, pp. 190-91.

${ }^{103}$ Ed. 1637, p. 193.
} 
wanted to lecture on Suetonius, whom he considered to be 'the most useful and pleasant writer of all'. ${ }^{104}$

In what follows, he explains that he has decided to read Suetonius's biographies rather than a work of universal history because they best illustrate the quirks of fate. Throughout the Lives of the Twelve Caesars, one can observe ( $\mathrm{r}$ ) evolutions which in world history are only visible after thousands of years and contemplate both the rise and the fall of Roman monarchy. ${ }^{105}$ Suetonius is the only Latin historian who paints a full picture of this period, since Tacitus barely discusses the reign of Augustus, and Velleius Paterculus is not to be trusted. ${ }^{106}$ Suetonius, by contrast, was both accurate and, even more importantly, sincere. Neither fear nor zeal kept him from telling the truth, and he made sure to write only about deceased emperors, remaining silent about Nerva, Trajan and Hadrian, under whom he lived and worked. In Zevecotius's opinion, Suetonius had revealed the greatest secrets (arcana) of the Roman empire in the briefest of books and was able to instruct young and old alike. ${ }^{107}$ Zevecotius's work, however, according to the Dutch historiographer Johannes Isacius Pontanus, who also contributed a liminary poem, was not an instrument for the education of youth, but instead for the instruction of kings. ${ }^{108}$ This assumption is reinforced by the physical format in which it circulated: while Goulart and Bernegger both produced didactic editions, the first targeting a general audience and the second Bernegger's own students, Zevecotius's book did not include the text of Suetonius and was therefore meant for readers who already knew the work or owned it - not just kings, obviously, but probably all manner of (present and future) statesmen.

In conclusion, for Zevecotius, too, eloquence, history and politics were closely connected, and he believed that to master these disciplines - and to be able to serve the state - it was necessary to read the ancient historians. Since Suetonius offered a precise and impartial account of the rise and fall of imperial rule, while also illustrating the fortunes which befell individual

104 Ed. 1637, p. 192: 'Historia enim sine eloquentia muta est, uti haec sine historia rudis. Quapropter extra ordinem quidem orandi argumenta a summis historicis petita volentibus praefigam, ordinarie vero Suetonium vobis interpretabor, authorem quo nec utiliorem ullum nec iucundiorem potui invenire.'

${ }^{105}$ Ed. 1637, p. 192: 'Quamvis enim plures, universam diversarum gentium historiam complexi, abunde placerent, tamen ... malui me ad singularia convertere, ubi unusquisque theatrum est ludentis fortunae; ubi conversiones, quas in magnis illis corporibus, regionibus inquam ac urbibus, post multa saepe annorum millia notamus, in principis cuiusque vita accidunt quotidie; ubi et monarchiae Romanae ortum et declinantem postea imperii statum possumus contueri.'

${ }^{106}$ Ed. 1637, p. 192: 'Totam huius rei scenam Suetonius noster aperit, et praeter illum e Romanis nemo. Nam Tacitus pauca tantum de Augusto et extrema commemorat. Velleius Paterculus foeda assentandi libidine corruptus vix usquam fidem meretur.'

${ }^{107}$ Ed. 1637, p. 192: 'Noster omnia et accurate persecutus est et, quod praecipuum duco, sincere. Veritatem enim ubique amat, a qua ne recedere vel metu vel studio videretur, defunctorum tantum principum res composuit. De Nerva, Trajano, Adriano ubique tacet, inter quos tamen vixit. Et brevi satis libello maxima rerumpublicarum arcana aperiens, et senes instruere et iuvenes potest docere.' Suetonius's impartiality was also highlighted by earlier 15th- and 16th-century commentators: see Crab, 'Henricus Petri's Editions of Suetonius' (n. 2 above).

108 Ed. 1637, sig. A3v: 'O librum egregiumque regiumque! / Non tu cymbalon es vagae iuventae, / reges discipulos habes monesque.' 
emperors, together with their military and political accomplishments, his Lives of the Twelve Caesars was an ideal point of departure for political instruction. Nevertheless, as Zevecotius used Suetonius's text to develop his own ideas on the government and preservation of the state, in the end his work is more revealing of his own views and the seventeenth-century context in which he developed them than of Suetonius and the original milieu in which the Lives were written. For these reasons, his Observata politica in Suetonium (and Florum, for that matter) definitely deserve further study in their own right; but we must now move on to the fourth and final case study, which examines the work of Bernegger's student Johannes Boeclerus.

\section{Johannes Boeclerus (1647)}

The German polyhistor Johannes Boeclerus (Johann Heinrich Boeckler, 1611-1672) spent most of his life in Strasbourg, where he first studied with Matthias Bernegger, subsequently taught at the local Gymnasium and in 1637 succeeded his former mentor as University Professor of Rhetoric. On Bernegger's death in 1640, Boeclerus delivered his funeral oration and also took over the Chair of History. In the aftermath of the Thirty Years' War, Boeclerus left for Sweden, where he taught Rhetoric and Politics at the University of Uppsala from 1649 and was appointed state historiographer in Stockholm in 1650. Four years later he returned to Strasbourg, where he regained his old position and was rergarded as one of the university's most important professors until his death in 1672. Not surprisingly, Boeclerus wrote many political and historical works, among them a commentary on Hugo Grotius's De iure belli ac pacis (1663/4) and a history of the Swedish-Danish war (posthumously printed in 1679). ${ }^{109}$ Like Lipsius and Bernegger before him, moreover, he also engaged in the political reading of ancient historians, which resulted in editions with commentaries of Cornelius Nepos (1640), Velleius Paterculus (1642), Tacitus (Annals 1643, Histories 1648), Herodian (1644) and Suetonius (1647). ${ }^{110}$

Boeclerus's Dissertationes politicae in Caii Suetonii Tranquilli Caesares was part of a larger edition of Suetonius which was published in Strasbourg by the university printer Johannes

109 To date there is no comprehensive survey of Boeclerus's life and works. For a succinct bio-bibliography, with further literature, see W. Kühlmann, 'Boeckler, Johann Heinrich', in Der Neue Pauly: Supplemente, VI, Stuttgart and Weimar, 2012, pp. 122-3. Boeclerus's dissertations on Suetonius, which are not listed by Kühlmann, have never been studied.

110 On Boeclerus's political reading of the ancient historians, especially Tacitus, see, in addition to the literature cited above in n. 43, Etter, Tacitus (n. 4 above), pp. 160-61, and M. Disselkamp, Barockheroismus: Konzeptionen 'politischer' Größe in Literatur und Traktatistik des 17. Jabrbunderts, Tübingen, 2002, pp. 69-82; on his reading of Lipsius's Politica see also Lipsius en Leuven: Catalogus van de tentoonstelling in de Centrale Bibliotheek te Leuven, 18 september-17 oktober 1997, ed. G. Tournoy et al., Leuven, 1997, pp. 220-22. Boeclerus's general views on the disciplines of law, ethics and politics are further discussed by T. J. Veen, 'Recht en nut: Studiën over en naar aanleiding van Ulrik Huber (16361694) (mit ausführlicher deutscher Zusamenfassung)', PhD diss., Rijksuniversiteit Groningen, 1976, pp. 84-7, 12332, 351-5, and W. Weber, Prudentia gubernatoria: Studien zur Herrschaftslehre in der deutschen politischen Wissenschaft des 17. Jabrbunderts, Tübingen, 1992, pp. 140-45 and passim. 
Philippus Mülbius in 1647 and reissued there in 1688 at the expense of Josias Staedelius. As Boeclerus explains in his letter to the reader, his own work accompanies the learned and useful commentary of Isaac Casaubon, which had been applauded by scholars everywhere. By the 1640s, however, hardly any copies of the original 1595 and 1596 Geneva editions or of the enlarged 1610 Paris edition were still available; so Mülbius decided to publish a new edition, printing the text of Suetonius's Lives of the Twelve Caesars, his extant Lives of the Grammarians and Rhetoricians and biographies of Horace and Pliny the Elder, along with some fragments of other lost works, ancient testimonies on Suetonius, Poliziano's famous Praefatio in Suetonium, an excerpt from Vossius's De historicis Latinis, a very elaborate index, Casaubon's Animadversiones and, last but not least, Boeclerus's Dissertationes politicae. ${ }^{111}$ The result is a voluminous scholarly edition, aimed at more advanced readers wishing to study Suetonius's text in great detail.

Boeclerus himself, as he states at the end of his political dissertations, had not written a commentary on Suetonius. ${ }^{112}$ In the preface he admitted that Suetonius's work was difficult to understand, partly because of his allusions to many ancient customs and institutions which were never explained; ${ }^{113}$ unlike Casaubon, however, Boeclerus did not attempt to provide these explanations himself. In contrast to Goulart, Bernegger and Zevecotius, moreover, he did not use Suetonius's text for moral-political instruction. Instead, Boeclerus wrote his own, alternative version of the biographies from Caesar to Domitian, focusing on the emperors' public rather than their private lives. ${ }^{114}$ Throughout his dissertations, which do not follow the order of Suetonius's text but have an internal organization of their own, Boeclerus devoted scarcely any space to typically 'Suetonian' features such as the appearance, love life, death and funeral of the emperors, nor did he mention any omens. While Suetonius - and thus Goulart, too - had painted a complete portrait of the emperors' personalities, listing their virtues as well as their vices, Boeclerus discussed only those qualities relevant to their statesmanship and their role as military

111 Ed. 1647, ‘Ad lectorem', sig. )(3': 'Inter ea quae vir summus Isaacus Casaubonus antiquis auctoribus illustrandis scripsit, cumprimis doctrina et utilitate videntur praecellere Animadversiones in Suetonium, quae tanto sunt applausu ubique ab eruditis exceptae, quanto non temere aliud in hoc genere momentum. Earum ergo, distractis pridem exemplaribus quae Genevae et auctius Parisiis prodierant, cum nulla complures iam per annos studiosis facultas esset, natum bibliopolae nostro consilium novae editionis, quam hic damus. Addidi a me Dissertationes politicae ... curavi.'

112 Ed. 1647, 'Dissertatio in Domitianum', \$8 (p. 150): 'Excerpta, non commentarios dedimus.'

${ }^{113}$ Ed. 1647, 'Praefatio', $\$ 12$ (p. 5): ‘... cum ceteri quidem facile, Suetonius a paucioribus intelligatur', and $\$ 19$ (p. 7): 'Accedit incredibilis antiquitatum Romanarum, rituum, morum, monumentorum ubertas... Id nonnullos hodie deterret a lectione Suetonii, opinione obtentuque difficultatis (plurima enim tanguntur in talibus, est ubi et alluduntur potius quam explicantur) quod interim magno incitamento ad capessendam tam utilem cognitionem esse debebat.'

114 Although Boeclerus discussed all of the Roman emperors, he paid most attention to Julius Caesar (17 pages), Augustus and Tiberius (24 pages each), and Caligula and Nero (16 pages each). He was particularly interested in Tiberius: he concluded his 1635 course on Tacitus's Annals with an Oratio de Tiberii Caesaris principatu (printed in Strasbourg the following year), and his student Veit Ludwig von Seckendorff delivered a speech entitled Tiberii revelati forma sive ratio status aperta facie deprehensa in 1643; see Kühlmann, 'Matthias Bernegger' (n. 43 above), p. 57 n. 117, and id., 'Geschichte als Gegenwart' (ibid.), p. 331 n. 39. 
and political leaders (mentioning, for example, Julius Caesar's ambitio and prudentia, but not his libido). In addition, he returned the narratives to their original historical context. Whereas Suetonius took it for granted that his readers had a thorough command of Roman history, which would allow them to contextualize the imperial biographies, Boeclerus added such background information as was necessary to understand the events reported by Suetonius, discussing, for instance, at the beginning of his Life of Julius Caesar the condition of the Roman republic as inherited by Caesar, ${ }^{115}$ or the ways in which other politicians such as Cicero and Cato sought to resolve the crisis. ${ }^{116}$ For information of this kind Boeclerus did not rely on earlier commentators on Suetonius, whose works he knew yet did not use, ${ }^{117}$ but on other ancient historians who recorded the same events: Tacitus, Plutarch, Cassius Dio, Appian, Velleius Paterculus, Florus and many others. The names of Boeclerus's sources are duly noted at the beginning of each dissertation, ${ }^{118}$ as well as indicated in the margins throughout; a thorough collation of these parallel passages, claims Boeclerus in his preface, would be equivalent to a commentary. ${ }^{119}$

Consequently, the focus shifted from the Roman emperors to the Roman empire, and Boeclerus seems to have written a work of imperial history rather than a collection of imperial biographies. Arguing, moreover, that the Roman empire was larger and greater than any other state, he claimed that those writing imperial history (Historia Augusta) dealt with the history, not of a single nation, but of the entire world. ${ }^{120}$ So the dissertations are strictly historical; and, in spite of his statement that 'Suetonius has never minded being adapted for the usefulness of political studies, ${ }^{121}$ it is difficult to see how this work makes Suetonius relevant to Boeclerus's own times. In his preface, he paid ample attention to the stylistic and literary qualities of Suetonius's Lives of the Twelve Caesars, calling his dictio elegant and pure ('emendatissima venustate', 'elegantissima puritate'), comparing his succinct style of writing to that of Caesar and Cornelius Nepos, and

${ }^{115}$ Ed. 1647, 'Dissertatio in Julium Caesarem', \§3-4 (pp. 8-9).

${ }^{116}$ Ed. 1647, 'Dissertatio in Julium Caesarem', \$30 (p. 21).

117 See Boeclerus's judgement on his predecessors in his letter 'Ad lectorem', ed. 1647, sig. )(3v: 'Proxima laus Torrentio debetur, cuius notae non quidem diffusae sed plerunque graves ac eruditae sunt. Beroaldus in magna copia et ubertate commentandi saepius dormitat aut in minutiis moratur, sicut et Sabellici paraphrasis non pauca habet quae merito talibus viris ignoscimus, vehementerque interim eorum in re litteraria instauranda studium commendamus. Quae Pulmannus, Erasmus, Glareanus, Ursinus, Lipsius, Vinetus, Egnatius, Gruterus annotaverunt pauciora sunt. Cetera in aliis philologorum scriptis criticis passim continentur, qualia in unum conducta ... ingens volumen possunt conficere.'

118 See, e.g., ed. 1647, 'Dissertatio in Julium Caesarem', $\$ 1$ (p. 8), or 'Dissertatio in Octavium Caesarem Augustum', $\$ 7$ (p. 28).

${ }^{119}$ Ed. 1647, 'Praefatio’, $\$ 18$ (p. 7): 'Itaque ... brevissimo ambitu ingentem materiam emetitur. Quod nemo melius aestimabit, quam qui Caesarum, quos ille narrat, historiam pleno contextu ab aliis tractatam cognoverit. Ea enim comparatio, praeterquam quod commentarii vicem fungetur, etiam recludet penetralia eius copiae, quam in tam reciso opere pauci suspicantur, nedum animadvertunt.'

${ }^{120}$ Ed. 1647, 'Praefatio', \S2-11, esp. 4-5, 9 (pp. 1-4).

121 Ed. 1647, Dedicatory letter to Daniel Imlinus, sig. )(1 v: '... utilitati civilium studiorum se pro captu saeculi et conditione disciplinae accommodari nunquam aegre tulit.' 
praising his thematic composition ('per species actus morisque'). ${ }^{122}$ Moreover, he greatly admired Suetonius's eruditio, gravitas and prudentia, stressing that from his work alone one could learn more about antiquity than from many other historians put together and could retrieve large amounts of information in a brief time. ${ }^{123}$ In his epistolary dissertation on the right study of politics, Boeclerus also recommended Suetonius both as a model of good style and as a font of history and prudence; ${ }^{124}$ but neither in this work nor in his 1647 Dissertationes politicae did he specify which lessons could be drawn from Suetonius.

It is interesting to note, however, that, for Boeclerus, imperial history amounted not only to universal history but also to providential history: as explained at the beginning of his preface, it was God's will that the Roman empire and emperors should surpass all others in grandeur and greatness. ${ }^{125}$ In his dissertations, Boeclerus was mostly concerned with the growth and government of the Roman empire, showing how each of the emperors ruled the state. He was particularly interested in the origins of the empire, asking how one man (Julius Caesar) could bring about such a revolution, abandoning the Roman republic and establishing the principate. A large part of Boeclerus's Dissertatio in Julium Caesarem is devoted to the development of Caesar's political career; and, like Goulart, he expounded the measures taken by Caesar and discussed their effects. ${ }^{126}$ Much more than Goulart, however, Boeclerus highlighted God's role in history, emphasizing that it was the deity who had singled out Caesar and steered him to fulfilling the divine plan. ${ }^{127}$ By the mid-first century BC, he explains, the Roman republic was in such turmoil, and lawlessness was so rampant that it required a very strong man to solve the crisis. Fortunately, God did not leave the Romans to their own devices, nor did he hand them over to a tyrant for punishment. Instead, he decided to save them by sending a hero, for only with the deity's support can new states be founded and existing ones kept from ruin. ${ }^{128}$

Characterizing Julius Caesar as a hero (heros), and believing him to have been an instrument in God's hands, Boeclerus painted a rather positive picture of the man. He was certainly a better candidate for absolute rule than Pompey, who may have been more moderate

\footnotetext{
122 Ed. 1647, 'Praefatio', \$\$ $\$ 12-15$ (pp. 4-6).

123 Ed. 1647, 'Praefatio', \$ $\int 516-19$ (pp. 6-7).

${ }^{124}$ I read Boeclerus's 'Dissertatio epistolica de studio politico bene instituendo' in his Bibliographia bistorico-politicophilologica curiosa, Frankfurt, 1677, sig. A8v: 'Quia vero politicum hominem stylus vel maxime apertus et planus, non vulgaris tamen aut vilis decet, nemo tibi potior erit quem sequere auctor quam Julius Caesar, Cornelius Nepos et qui iam antea tibi historiae prudentiaeque nomine commendandus fuit, Suetonius.' On Zevecotius's similarly entitled work, see n. 99 above.

125 Ed. 1647, 'Praefatio', \\S3-5 (pp. 1-2).

${ }^{126}$ Ed. 1647, 'Dissertatio in Julium Caesarem', $\int 58-20$ (pp. 10-16).

127 Ed. 1647, 'Dissertatio in Julium Caesarem', $\int \$ 5-7,21$ (pp. 9-10, 16-17). God's role in history is also evident from Boeclerus's 'Dissertatio in Octavium Caesarem Augustum', $\int \$ 1,7-9$ (pp. 25, 28-31).

${ }^{128}$ Ed. 1647, 'Dissertatio in Julium Caesarem', \22-4 (pp. 17-18). Boeclerus thus held a different opinion from Glareanus, who believed that the emperors were possessed by the devil: see Crab, 'Henricus Petri's Editions of Suetonius' (n. 2 above).
} 
and equitable than Caesar but who also acted more cunningly. ${ }^{129}$ Moreover, Boeclerus praised Caesar's sharp mind, his military genius, eloquence, diligence, swiftness, efficiency and prudence; and he named several later princes (such as Alfonso of Aragon, Louis XII and King James) who took Julius Caesar as their model. ${ }^{130}$ Admittedly, Caesar also had his weaknesses: he waged a few unjust wars, sometimes disregarded the law, showed too little modesty and too much ambition. ${ }^{131}$ According to Boeclerus, however, even his vice-ridden plans were effective, punishing the republic's vices with his own. ${ }^{132}$ In any case, there is no doubt that he was unjustly murdered, for 'no tyrant ever caused so much harm to the Roman republic as Brutus and Cassius did by killing Caesar. ${ }^{, 133}$

By sending Julius Caesar to the world, God enabled the Roman state to make a fresh start. Under his reign and that of Augustus, which Boeclerus called the 'aetas imperatoria', the Roman empire finally knew peace, and the birth of God's son among its citizens added to its glory. ${ }^{134}$ Sadly, this revival was followed by a period of tyranny and corruption, started by Tiberius and continued under Caligula, Claudius and Nero. The reigns of Galba, Otho and Vitellius were again characterized by confusion and disorder; and while Vespasian and Titus restored the empire to its former strength, under Domitian it fell prey to tyranny once more. ${ }^{135}$ When read as a whole, Suetonius's work therefore nicely illustrates the rise and fall of the Roman empire, showing that over a period of nearly two centuries, from the birth of Julius Caesar in 100 BC to Domitian's demise in AD 96, history came full circle and - ultimately - repeated itself. ${ }^{136}$

It is beyond the scope of this article to establish whether Boeclerus's Dissertationes politicae in Caii Suetonii Tranquilli Caesares were in line with his political commentaries on other classical authors, not all of which have been studied individually, let alone in connection to one another. It is clear, nonetheless, that since Boeclerus used Suetonius's biographies as a starting point for his own account of imperial history, focusing on the establishment, development and organization of the Roman principate, which he saw as essentially determined by God's will, he produced a book which was very different from that of his teacher Bernegger. Yet in spite of the differences in contents and approach, the didactic procedure underlying both works was basically the same. Like Bernegger, Boeclerus must originally have divided up Suetonius's text among his students

\footnotetext{
${ }^{129}$ Ed. 1647, 'Dissertatio in Julium Caesarem', $\$ 23$ (p. 17).

${ }^{130}$ Ed. 1647, 'Dissertatio in Julium Caesarem', $\$ \$ 25-9$ (pp. 18-21).

${ }^{131}$ Ed. 1647, 'Dissertatio in Julium Caesarem', $\$ \$ 25,29,31-2,36$ (pp. 18, 20-22, 24).

132 Ed. 1647, 'Dissertatio in Julium Caesarem', \$5 (p. 9).

133 Ed. 1647, 'Dissertatio in Julium Caesarem', $\int \$ 33-5$ (pp. 22-4, at 24): 'Nemo tyrannus unqam tantum reipublicae nocuit quantum Brutus et Cassius, tyrannidis, ut videri volebant, expulsores.' In his 'Dissertatio in Octavium Caesarem Augustum', \$6 (p. 28), Boeclerus regarded Augustus's punishment of Caesar's murderers an act of piety.

${ }^{134}$ Ed. 1647, 'Praefatio', $\$ \$ 66-7$ (p. 2).

135 Ed. 1647, 'Praefatio', \$10 (p. 4).

${ }^{136}$ Ed. 1647, 'Praefatio', $\$ 11$ (p. 4).
} 
for oral presentation, as he concludes by saying that the political observations were intended for academic exercise. ${ }^{137}$ Evidence of this is found in eight booklets, printed in Strasbourg by Mülbius between November 1645 and April 1647, each of which contains part of Boeclerus's dissertations on Suetonius as they were defended by his students with him presiding. ${ }^{138}$ Since the text and layout of the individual dissertations are identical to that of the 1647 edition, it is again reasonable to assume that, having discussed Suetonius's Lives of the Caesars in class, Boeclerus first had the Dissertationes politicae printed by and for his students, and then reissued the work under his own name for use by a broader readership. Remarkably, in addition to the traditional student inscriptions and their fellow pupils' laudatory poems, two of the booklets under consideration (containing the dissertations on Galba, Otho and Vitellius, which, as we have seen, were not covered by Bernegger) also have sets of corollaria. So it appears that, like his predecessor, Boeclerus, too, seized on particular passages in Suetonius's text to teach certain moral, political, legal and military lessons, asking, for example, 'whether Viriathus's murder was justified', 'whether it is acceptable for someone to be sentenced without trial', 'whether Otho himself should have been present in battle' and 'whether it is permissible to destroy holy places in order to defeat the enemy'. ${ }^{139}$

Even though in this case we also lack the students' answers, these questions show that Bernegger and Boeclerus belonged to the same political-exegetical tradition. This does not imply, however, as has been assumed by earlier scholars, that Boeclerus simply carried on Bernegger's work. ${ }^{140}$ Since, in the absence of Johannes Freinsheim, Boeclerus helped Bernegger publish his editions of the ancient historians, ${ }^{141}$ he was naturally well informed about his teacher's projects. In his letter to the reader, he explained that Bernegger had started working on an elaborate edition with commentary of Suetonius's Live of the Twelve Caesars, which would incorporate not only Casaubon's notes but also those of other scholars. As only the Life of Julius Caesar and part of

137 Ed. 1647, 'Dissertatio in Domitianum', \$8 (p. 150): 'Atque haec sunt, quae in Suetonii Caesares ad usum academicarum exercitationum per potiora quaedam observationis politicae capita ... annotare voluimus.' Boeclerus probably followed the same procedure for Tacitus, for both in his 1643 edition of Tacitus's Annals (at the end of the preface) and in the 1648 edition of the Histories (at the end of the volume) he listed the names of the students who publically defended parts of the text.

${ }^{138}$ From their title-pages, it can be gathered that the political dissertation on Caesar was defended by Achatius a Layming on 20 November 1645, that on Augustus by Leonhardus Weiss Junior on 15 May 1646, that on Tiberius by Johannes Carolus Schmidius on 28 May 1646, that on Caligula and Claudius by David Thoman in October 1646, that on Nero by Johannes Fridericus Krauth in November 1646, that on Galba and Otho by Johannes Thomas Eberhard in April 1647, that on Vitellius by Johannes Laurentius Holler on 8 May 1647 and that on Vespasian, Titus and Domitian by Michael Riebel on 19 May 1647 (though the latter two were also originally scheduled for April).

139 VI.2 (ad Galb. 1): 'An Viriathi caedes iure defendi possit?'; VI.5 (ad Galb. 14): 'An unquam quisquam inauditus sive indicta caussa iuste condemnari possit?’; VI.8 (ad Oth. 9): ‘An Otho ipse debuerit interesse praelio?’; VII.4 (ad Vit. 15): 'An hostis impugnandi destruendique caussa loca sacra destruere aut urere liceat?'

140 Bünger, Matthias Bernegger (n. 41 above), p. 299: 'Auch geht die von Böcler veranstaltete Suetonausgabe auf diese Arbeit Berneggers zurück.'

${ }^{141}$ See Etter, Tacitus (n. 4 above), p. 160. 
that of Augustus had been finished, he hoped that Freinsheim would continue the series. ${ }^{142}$ Offering 'excerpts' rather than a commentary, however, Boeclerus for his part aimed at brevity; consequently, he could not discuss every detail, nor pursue matters in greater depth. ${ }^{143}$ Moreover, although Boeclerus continued the educational method of Bernegger and, like him, presented his students with moral-political questions about Suetonius's text, the dissertations arising from these lessons were strictly historical and, therefore, original, resembling Bernegger's neither in content nor in approach.

\section{Conclusion}

During the first half of the seventeenth century, Suetonius's Lives of the Twelve Caesars came to be read and interpreted in novel ways. As in earlier times, commentators still recommended this work for its elegant Latin style, its accuracy and impartiality, and its wealth of information on life at the imperial court. Yet, while fifteenth- and sixteenth-century humanists were more concerned with the antiquarian aspects of Suetonius's Lives than with the historic events recorded in them, the scholars discussed in this article also envisaged his collected biographies as an important piece of imperial history, documenting the rise and fall of absolute rule and, for some of them, also providing evidence of God's role in history. Unlike their predecessors, moreover, seventeenthcentury commentators on Suetonius also considered his work a source of prudentia civilis and interpreted the Lives from a moral and/or political point of view.

Since Simon Goulart, Matthias Bernegger, Jacobus Zevecotius and Johannes Boeclerus were all working within different literary genres, their political responses to Suetonius's Lives of the Twelve Caesars vary greatly in form and content. Summarizing, one could say that their works were increasingly detached from the text of Suetonius, both in the literal and figurative sense. First, it is conspicuous that whereas Goulart's notae were printed in its margins and Bernegger's diatribae

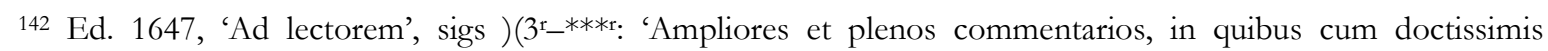
Casauboni curis aliorum quoque ingeniorum labores et notae, non eae modo quae in Parisiensi volumine comparent sed quae alibi queunt reperiri aut industria editoris addi, exhiberentur, magnus noster Berneggerus, dum vita manebat, inchoaverat, absolutaque Caesaris vita, partem Augusti quoque ad eam formam publicaverat, cuius instituti operisque continuationem a clarissimo amicissimoque Freinshemio expectamus.' As noted in n. 52 above, the diatribae on Caesar, Augustus and Titus appeared from Bernegger's press in 1654, but Freinsheim did not continue the series. He may have had further plans in this direction, though, for Graevius's variorum editions published in Utrecht in 1672 and 1691 contain an impressive 'index Berneggerianus', which the printer, Gisbertus a Zyll, claims to have bought from Freinsheim's heirs (ed. 1672, 'Ad lectorem', sig. ***4v): 'His omnibus accessit index uberrimus Matthiae Bernecceri, viri praeclari, quem ab eius generi, Johannis Freinshemii, haeredibus aere suo typographus comparavit.'

${ }^{143}$ Ed. 1647, 'Dissertatio in Domitianum', $\$ 8$ (p. 150): 'Brevitas nobis pro lege fuit et nunc pro argumento veniae erit, si qua minus sunt a nobis expresse pensiculateque posita. Excerpta, non commentarios dedimus, itaque multa nobis omittenda fuerunt, multa non amplius quam tangenda.' Note that the term excerptum is used here not in its traditional sense of 'extract (from an existing work)'; rather it denotes the selective character of Boeclerus's own biographies (cf. supra, n. 114). 
followed after (parts of) Suetonius's text, Zevecotius's observata included only lemmata, and Boeclerus's dissertationes were published autonomously. Although the lemmata still in a way connected Zevecotius's observations to the text of Suetonius, given the independent character of his work and that of Boeclerus, neither were commentaries in the traditional sense. Both Goulart and Bernegger, as I have shown, stayed very close to Suetonius's text. Explaining difficult words, offering background information and discussing textual and historical problems, Bernegger sought to clarify what Suetonius had written and make it as explicit as possible. He thus followed in the footsteps of earlier commentators such as Beroaldo, Torrentius, Gruterus and Casaubon, whose works he knew and used. Goulart, for his part, practised what previous commentators had only preached: by analysing and judging the emperors' every move, he guided the reading and interpretation of Suetonius's text. By contrast, Zevecotius used Suetonius's Life of Julius Caesar as a pretext for expressing his own political ideas, and Boeclerus gave his own, alternative account of imperial history. But even if Bernegger's disputations were strictly philological and Boeclerus's dissertations strictly historical, when teaching Suetonius's Lives, they both also asked moral and political questions.

Consequently, each of the commentators under discussion had his own way of making Suetonius's text relevant to their own time. In spite of the similitudo temporum, the works of Goulart, Bernegger, Zevecotius and Boeclerus contained only few references to the seventeenthcentury political situation; nor did they put forward any (anti-)absolutist propaganda or any discussion of the principate. Instead, they reflected on the qualities and duties of rulers more generally, asking how a good ruler ought to behave and how he should govern, defend and preserve his country. Like earlier fifteenth- and sixteenth-century commentators, Goulart read Suetonius's work as a mirror-for-princes, considering the emperors as exempla (contraria) of virtues to be fostered and vices to be shunned. Bernegger, Zevecotius and Boeclerus, following Lipsius, also coupled the study of history to that of politics; but, unlike Goulart, they did not present the emperors portrayed by Suetonius as simple models for imitation. While Goulart paid equal attention to the the private and public lives of the emperors, his successors were solely interested in their achievements as statesmen and commanders. Sometimes they, too, judged the emperors from an historical perspective, pointing out what they got right and what they got wrong. Mostly, however, they used Suetonius's text as a vehicle to discuss broader moral, political, legal and military issues. Zevecotius, as we have seen, held very strong views on such topics, so that his work qualifies as a political handbook. For Bernegger, on the other hand, and presumably also for his pupil Boeclerus, the questions evoked by Suetonius seem to have been more important 
than the answers. Instead of giving their students specific political precepts, they taught them sententiae and exempla which would be useful for arguing in utramque partem.

So in the end, the scholars discussed here produced four very different books, which were printed for different readerships. Zevecotius's handbook targeted (present and future) statesmen already familiar with Suetonius's work. Goulart's didactic edition, on the other hand, was intended for the general public and especially for new, mostly younger, readers, while Bernegger's disputations and Boeclerus's dissertations, though initially meant only for their own students, were later reprinted for a wider - and, in the case of Boeclerus, a more scholarly - audience. This shows that, in the early seventeenth century, all types of readers were believed to be able to profit from Suetonius's work, both in their private and, especially, in their professional lives. Not coincidentally, three of the four authors discussed here were active within university education, training young men for a career in administration or government. To this end, the Lives of the Twelve Caesars was very appropriate reading, since Suetonius provided valuable instruction in the various disciplines needed to participate in contemporary debates and decision-making processes, such as history, law, rhetoric, ethics and politics. By staging disputations, moreover, Bernegger's and Boeclerus's students were given an excellent opportunity to bring this newly acquired knowledge and theory into practice. 